8-1975

\title{
A natural phonology and morphophonemics of Chimalapa Zoque
}

Lyle M. Knudson Jr.

How does access to this work benefit you? Let us know!

Follow this and additional works at: https://commons.und.edu/theses

Part of the Linguistics Commons

\section{Recommended Citation}

Knudson, Lyle M. Jr., "A natural phonology and morphophonemics of Chimalapa Zoque" (1975). Theses and Dissertations. 2806.

https://commons.und.edu/theses/2806

This Thesis is brought to you for free and open access by the Theses, Dissertations, and Senior Projects at UND Scholarly Commons. It has been accepted for inclusion in Theses and Dissertations by an authorized administrator of UND Scholarly Commons. For more information, please contact und.commons@library.und.edu. 
A NATURAL PHONOLOGY AND MORPHOPHONEMICS

OF CHIMALAPA ZOQUE

\author{
by \\ Lyle M. Knudson, Jr. \\ Bachelor of Arts, California State \\ University at Los Angeles, 1968
}

A Thesis

Submitted to the Graduate Faculty

of the

University of North Dakota

in partial fulfillment of the requirements

for the degree of

Master of Arts

Grand Forks, North Dakota

August

1975 
975

781

This Thesis submitted by Lyle $M$. Knudsen, in. in partial? fulfil\} . ~ mint of the requirements for the Degree of Master of Arts from the University of North Dakota is hereby approved by the Faculty Committee under whom the work has been done.
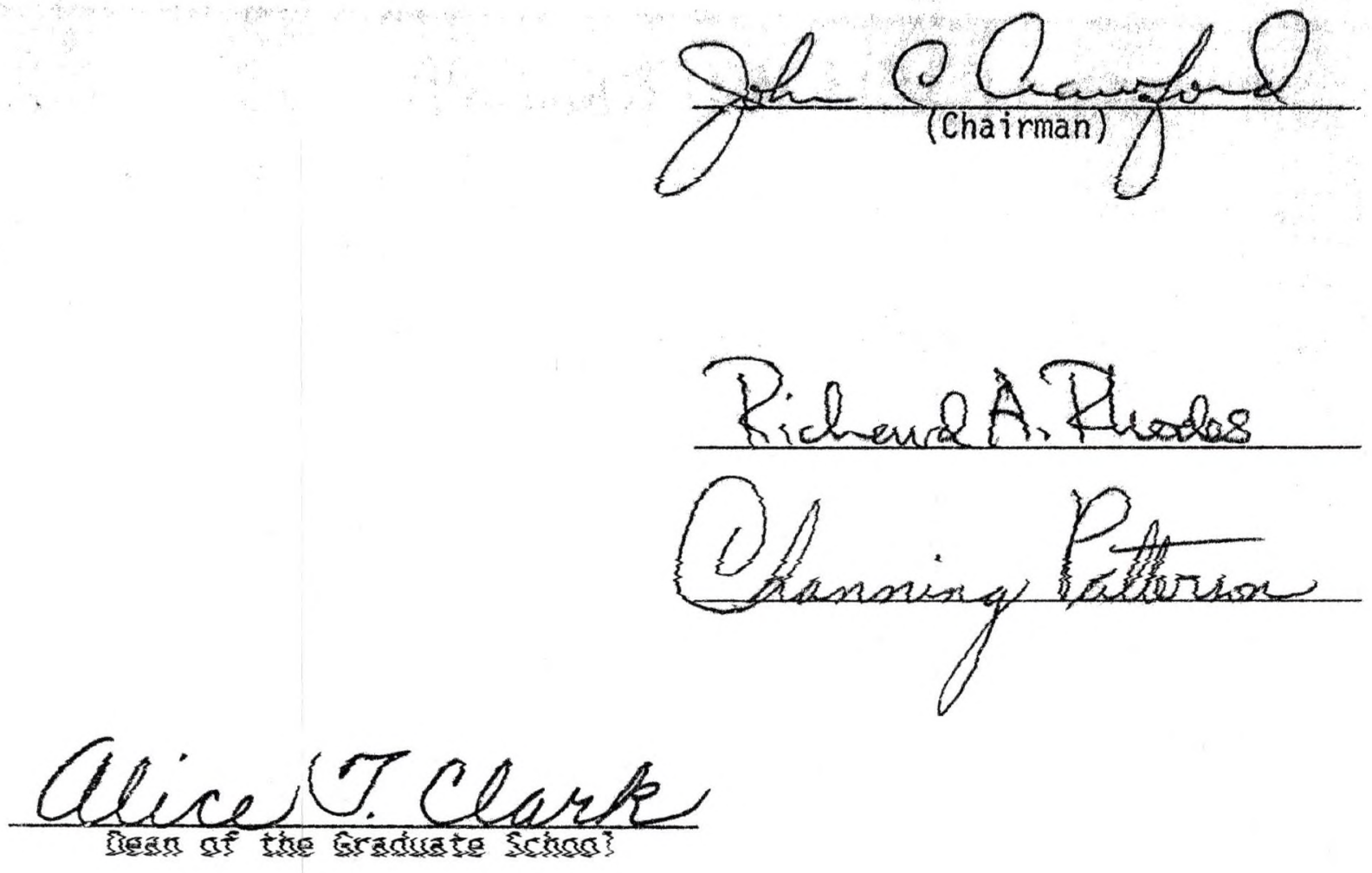

is 


\section{Permission}

Title A Natural Phonology and Morphophonemics of Chimalapa Zoque

Department

Linguistics

Degree Master of Arts

In presenting this thesis in partial fulfillment of the requirements for a graduate degree from the University of North Dakota, I agree that the Library of this University shall make it freely available for inspestion. I further agree that permission for extensive copying for scholarly purposes may be granted by the professor who supervised my thesis work or, in his absence, by the Chairman of the Department or the Dean of the Graduate School. It is understood that ary copying or publication or other use of this thesis or part thereof for financial gain shall not be allowed without my written permission. It is also understood that due recognition shall be given to me and to the University of North Dakota in any scholariy use which may be made of any material in my thesis.

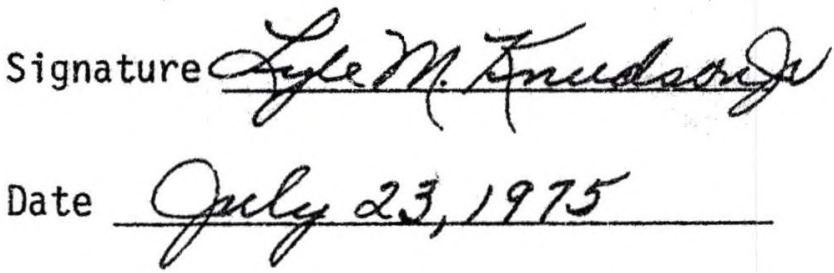




\section{ACKNOWLEDGEMENTS}

I wish to acknowledge my indebtedness to the Zoque speakers of Santa María Chimalapa, Oaxaca, Mexico, who so freely and helpfully are teaching me their language, and in particular two young men, Lucio González and Nazario Mendoza, who provided the bulk of the data used in this analysis. I wish to express my appreciation to those men who made up my Advisory Committee: Dr. John Crawford, chairman, Dr. Channing Patterson, and Richard Rhodes. I am especially indebted to Richard Rhodes for theoretical and practical advice with regard to the model used, and for the many insights he has provided in the analysis. 


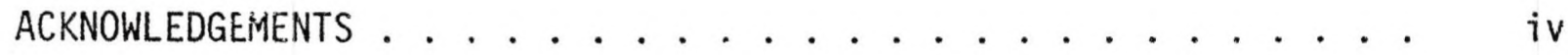

ABSTRACT ............................... vii

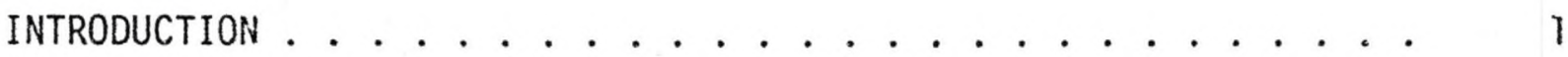

Chapter

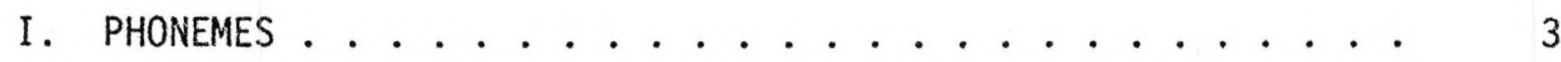

Feature Matrices . . . . . . . . . . . . . 3

Native feature matrix ............. . 4

Spanish feature matrix . . . . . . . . . . 5

Phonemic Contrasts ............... . . 6

II. ALLOPHONIC PROCESSES ................. . . 9

Stress . . . . . . . . . . . . . . . . 9 9

Vowel Lengthening and Rearticulation . . . . . . . . . 12

Palatalization ................ . . . 17

Sonorant Devoicing . . . . . . . . . . . . 20

Sonorant Syllabification . . . . . . . . . . . 22

Glottal Metathesis........... . . . . . 23

Obstruent Voicing ............... . . . 25

Identical Vowel Deletion . . . . . . . . . . . . 28

/i/ Deletion................ . . . 30

/ł/ Deletion ................... . . . 31

Glottal Reduction . . . . . . . . . . . . . 32

Glottal Deletion. . . . . . . . . . . . . . . . 33

$/ p /$ Lenition................. . . . 34

/h/ Friztion . . . . . . . . . . . . . . . . 35

Voiceless and Voiced Release . . . . . . . . . . 36

III. MORPHOPHONEMIC RULES . . . . . . . . . . . . . . . . 39

Consonant Duplication . . . . . . . . . . . . . . 39

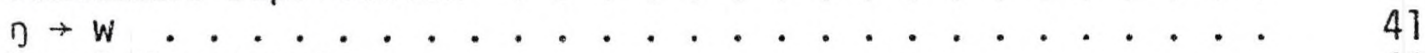

Vowel Epenthesis . . . . . . . . . . . . . . 42

/h/ Deletion . . . . . . . . . . . . . . . 44

Glottal Reduction . . . . . . . . . . . . 45

Vowel Harmony . . . . . . . . . . . . . . . . . . . . . . 46 46

Stative Vowel Raising . . . . . . . . . . . . 46 46

/y/ Deletion................ . . . 47

/†/ Umlaut................. . . . 49 
IV. CASUAL SPEECH PROCESSES ..................... 51

CS Glottal Metathesis . . . . . . . . . . . . . 51

CS Obstruent Voicing . . . . . . . . . . . 52

CS /c/ Deletion . . . . . . . . . . . . . 56

CS Sibilant Palatalization . . . . . . . . . . 57

CS /ga/ Deletion . . . . . . . . . . . . . . . 58

CS Glottal Deletion. . . . . . . . . . . . 59

$\mathrm{CS} / \mathrm{h} /$ Doubling ............... . . 59

V. LOAN PHONOLOGY. ................. . . 61

Internalized Loan Words . . . . . . . . . . . . . . . . 62

/0/ Raising. . . . . . . . . . . . . . 65

/f/ and /hw/ Substitution............ 66

$/ y /$ Epenthesis ................. . . 67

Other Processes . . . . . . . . . . . . . 68

VI. RULE ORDERING ..................... 70

Morphophonemic Rules . . . . . . . . . . . 70

Allophonic Processes . . . . . . . . . . . . 71

VII. MORPHEME STRUCTURE . . . . . . . . . . . . 75

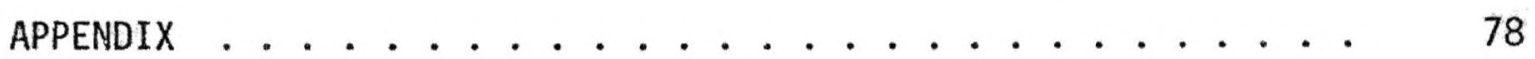

BIBLIOGRAPHY ............................ 81 


\section{ABSTRACT}

This thesis describes, by means of a modified natural phonological model, the phonological component of the Chimalapa Zoque language spoken in southern Mexico. An analys is of the processes occurring in the production of Zoque speech has resulted in the conclusion that a system of interrelated hierarchically-ordered rules and processes exist which generate the speech output of a native Zoque speaker. Four distinct sets of phonological ruies are described herein. Morphophonemic rules are those applied earlier to an abstract underlying form due to their grammatical conditioning and more radical changes. Following those rules are the careful speech allophonic processes which are physiologically motivated and which interact to produce the phonetic form that leaves the speaker's lips. When the Zoque speaker begins to talk faster and unguardedily, a separate set of co-existent casual speech allophonic processes are applied among the regular allophonic processes to produce a modified speech output. For those foreign words which find their way into a Zoque speaker's vocabulary, a special set of loan word rules are applied to assimilate unfamiliar forms into the regular Zoque phonological patterns. In addition to these four sets of rules and processes whose ordering relationships are summarized, there exist constraints on the segmental distribution within Zoque morphemes which are described axiomatically. 


\section{INTRODUCTION}

This paper describes the phonology of the Chimalapa Zoque language, hereafter referred to as CZ, using a modified natural phonological model. The phorological component of a grammar of $\mathrm{CZ}$ consists of morphophonemic rules and allophonic processes. In addition, casual speech processes form a superimposed or coexistent set of natural processes ordered among regular allophonic processes. Loar phonological rules exist to govern the assimilation of foreign words into the $\mathrm{CZ}$ lexicon. I am describing in this paper the specific rules which fall with 'n the above categories and the interrelationships which exist among them which require a partial ordering in their application. In addition, morpheme structure or segmental distribution is also described.

The model used in this paper draws its base from the natural phonological theory presented in recent years by David Stampe and others. This theory is an outgrowth of generative phonological theory which in general received its impetus in 1968 with the publishing of The Sound Pattern of English by Chomsky and Halle and which has evolved since then by changes and refinements. A sampling of those works affecting generative phonological theory in general and natural phonology in

TChimalapa Zoque is a language in the Zoque-Mixe Tanguage family spoken by an estimated 5,000 people centering in the area of the town of Santa María Chimalapa in the Isthmus of Tehuantepec region of the state of Oaxaca in southern Mexico. The present paper is based upon field work in the town of Santa Maria Chimayapa for a period of nine months in 1972 and 1973, interspersed by two 1 inguistic workshops held by the Summer Institute of Linguistics in Mitla, Oaxaca, during the fall 1972 and spring 1974. 
2

particular, along with other works consulted in the writing of this paper are included in the bibliography. 
CHAPTER I

PHONEMES

\section{Feature Matrices}

The Chimalapa Zoque language as spoken today includes a considerable number of foreign words, predominantly Spanish in origin. If one inciludes these loan words in his analysis, a feature matrix representing all the intersystemic contrasts to be found wou?d not provide an accurate account of the native phonemic inventory, restrictively speaking, since the two systems, Spanish and Zoque, conflict phonologically, and many of the Spanish loan words have not been completely assimilated, if we use the criteria assumed by Fries and Pike. 1 Those au whors imply that two or more phonemic systems may coexist within the speech patterns of a language, and I contend that this is the case for Chimalapa Zoque speatiers. In many cases the allophonic and morpheme structure conflicts coexist and are accepted by the Zoque speakers. This interpretation of Spanish forming a coexistent phonemic system rather than merging has been made in a related language in a similar situation. ${ }^{2}$ For this reason I am

${ }^{1}$ Charles C. Fries and Kenneth L. Pike, "Coexistent Phonemic Systems," Language. 25 (1949):29-50. On page 39 one assumption the authors make is: "A loan sequence of phonemes can be considered completely assimilated when (a) it parallels the seruences occurring in native materials, or is analogous to them; when (b) its occurrence in relation to grammatical boundaries is the same as sequences in native words; and then (c) the words containing it are in common use by the monolinguals; or ... When it serves as a pattorn for the development of new sequences in the native materials."

2 John C. Crawford, Totontepec llixe Pilunotagmemics (Norman, Okla.: Summer Institute of Linguistics, 1963), pp. 81-83. 
presenting two separate feature matrices: one providing a strictly native phonemic inventory, and another representing Spanish spoken in the Isthmus of Tehuantepec region of southern Mexico, that pattern which coexists with native $C Z$.

\section{Native Feature Matrix}

A matrix indicating the features of all the native $\mathrm{CZ}$ phonemes excluding Spanish loan words appears below. Consonant and vowel matrices are separated, with the glides /y,w,/ being included in the vowel matrix. Consonant matrix

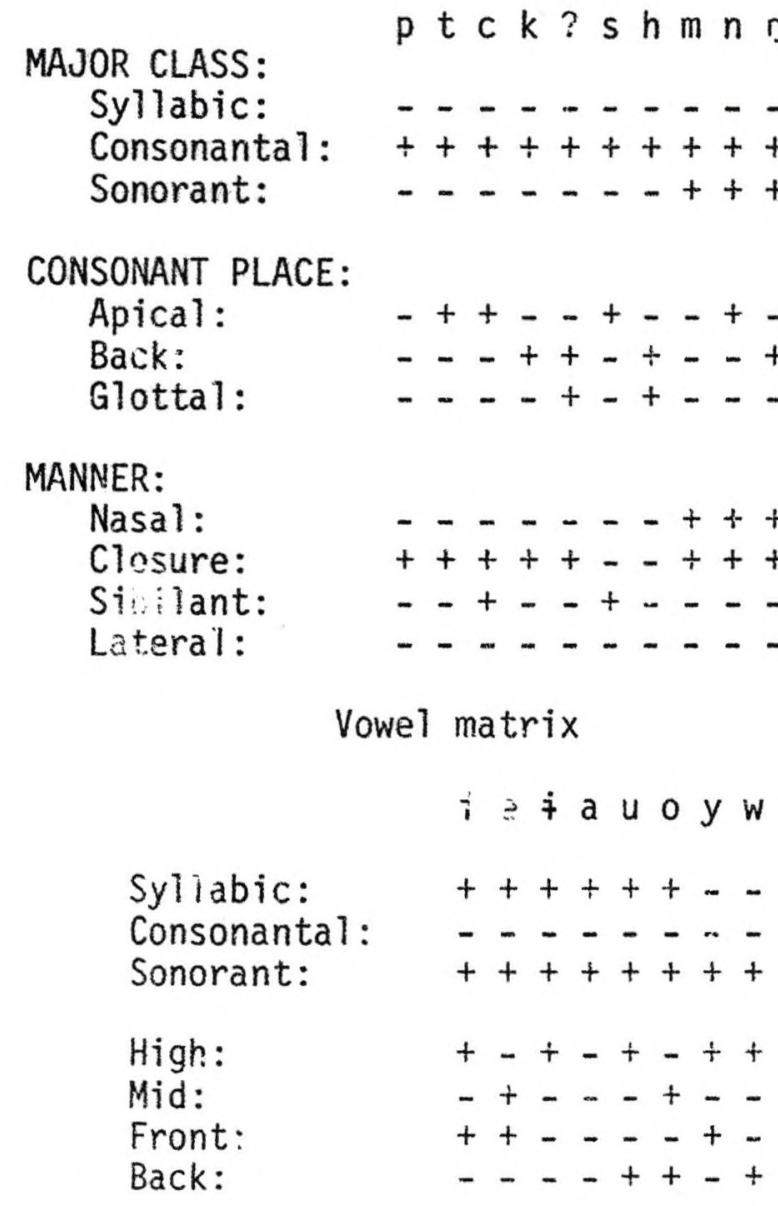


Spanish Feature Matrix

The following feature matrix represents the phonemes found in Isthmus Spanish, some of which coexist with, while others assimilate to, the Zoque pattern, either partially or completely as noted in the loan phonology section.

Consonant matrix

MAJOR CLASS:

$p t \check{c} k b d g f s h^{1} m n \tilde{n} l r \tilde{r}$

Syllabic:

Consonantal: $\quad++++++++++++++++$

Sonorant: $\quad \ldots \ldots+\cdots++\cdots++$

CONSONANT PLACE:

Apical:

Back:

Palatal:

Dental:

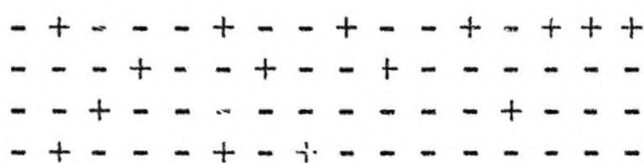

MANNER:

Nasal: $\quad \quad-\cdots-\cdots+\cdots++\cdots$

Closure: $\quad+++++++\cdots++++-\cdots$

Sibilant: $\quad-\cdots+\cdots-\cdots+\cdots$

Slow Release: $\quad \ldots+\ldots \ldots+\ldots$

Voiced: $\quad-\cdots+++\cdots+++++$

Lateral:

Vowel matrix

$\begin{array}{ll} & \text { i e a u o y w } \\ \text { Syllabic: } & +++++-- \\ \text { Consonantal: } & ------- \\ \text { Sonorant: } & +++++++ \\ \text { High: } & +--+-++ \\ \text { Front: } & ++--++- \\ \text { Back: } & ---++-+\end{array}$

IRegular Spanish $/ x /$ is realized as $/ h /$ in the Isthmus of Tehuantepec. 


\section{Phonemic Contrasts}

As implied in the first feature matrix, no phonemic contrasts occur within native words between voiceless obstruents $/ p, t, c, k /$ and their voiced counterparts /b,d, $3, g /$ since the latter are derived from the former. Those segments which share certain features which might cause them to be suspect phonemically are contrasted below.

The nasals / $m, n, g /$ contrast in identical environments as follows:

$/ \mathrm{m} /$ sampa 'he is warming himself'

/n/ sanpa 'he is becoming satiated'

$/ \mathrm{g} /$ sanpa 'he is clearing the land'

The apical obstruents $/ t, c, s /$ also contrast in identical environments:
/t/ tanpa 'he splits it'
/c/ canpa 'he pats it'
/s/ sanpa 'he is clearing the land'
$/ k, ?, h /$ contrast in identical environments both word-initially and medially:

$\begin{array}{lll}\text { /k/ ka?spa 'he paces' ciki? 'Peel it!' } \\ \text { /?/ ?a?spa 'he opens his mouth' či?i? 'Give it!' } \\ \text { /h/ ha?spa 'he is roasting it' cihi? 'Throw it!' } \\ \text { The bilabials /p, } \mathrm{m} / \text { contrast word-initially and medially: } \\ \text { /p/ pin 'person' hupi? 'Pull it!' } \\ \text { /m/ min } & \text { 'sweet potato' humi? 'cliff' }\end{array}$

The liquids $/ 1, r /$ have a very limited distribution in native $C Z$ words. $/ r /$ occurs predominantly word-medially between identical vowels, occurs word-finally in only one word, /nakstir/ 'sling', and in a few instances varies freely with word-initial /1/. /1/ occurs word-medially 
usually between non-identical vowels with few exceptions, and wordinitially but never word-finally. The two do, however, contra'st analogously:

\begin{tabular}{|c|c|c|}
\hline $11 /$ & $p \dot{q}\rceil \dot{q}$ & '(a tiny fish)' \\
\hline$r /$ & kuru & 'squirrel' \\
\hline
\end{tabular}

The six oral vowels /i,e,i,a,u,o/ contrast as follows:

/i/ pinpa 'he picks up'

/e/ penpa 'he plants (trees)'

/ + ?inpa 'he is sleepy'

/a/ panpa 'he is deaf'

/u/ punpa 'it is spilling'

/o/ ponpa 'it is burning'

The first three analogous contrasts of $/ i, e, \dot{i} /$ above also occur in identical environments:

/i/ pitpa 'he wraps it'

/e/ petpa 'he sweeps'

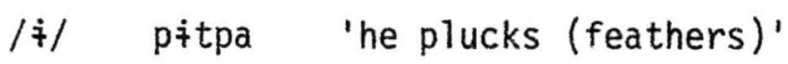

Phonemic contrasts for Spanish will not be provided in this paper since there are many published words available regarding that language and a focus on Spanish phonology is not the intent of this paper. The loan phonology section will discuss those areas of comparison or coexistence where pertinent.

If one were to analyze CZ native words and loan words as a body, as Wonderly has done for Chiapas Zoque, ${ }^{1}$ intersystemic contrasts would

William L. Wonderly, "Phonemic Acculturation in Zoque," Internatinnal Journal of American Linguistics 12 (1946):92-95, and "Zoque II: Phonemes and Morphophonemes," International Journal of American Linguistics 17 (1951):105-23. 
yield a different phonemic inventory which is, in effect, a blend of CZ and Spanish:

$/ p, t, c, \mathcal{C}, k, ?, b, d, g, \beta, s, h, m, n, \tilde{n}, \eta, 1, r, r, w, y, i, \dot{i}, u, e, o, a /$. 


\section{CHAPTER II}

\section{ALLOPHONIC PROCESSES}

Allophonic processes, for the purpose of this paper, may be considered those processes which are physically or mentally motivated or context-sensitive and are applied late in derivations to produce the phonetic form, or regular speech output, of a Zoque speaker.

The presentation of these processes is based more on frequency of occurrence or priority given to those processes which are more apparent than others, not on order of anjlication. Where rule ordering is pertinent it will be discussed, and an inventory of al1 rules in their order of appiication is provided later in this paper.

\section{Stress}

Stress in $\mathrm{CZ}$ is an allophonic process which is conditioned by grammatical and lexical considerations. 1 The placement of stress, when predictable, is determined by phonological word boundaries. A phonological word, or simply "word" in this section, in CZ is an utterance of speech involving from one to several syllables which usually is a single grammatical word, but may consist of more than one grammatical word, as in a noun phrase, verb phrase, or a complete clause. I am inclined to agree with Bolinger that the location of sentential stress or

For a discussion of grammatical effects on phonology, I refer the reader to Richard $A$. Rhodes, "Non-phonetic Environments in Natural Phonology," in Papers from the Parasession on Natural Phonology, Chicago Linguistic Society (April 1974):285-96. 
accent is as much a matter of information as of structure, and is not solely explainable by syntax or morphology. 1 There are, however discernible patterns of stress placement occurring in $\mathrm{CZ}$ which are described herein.

Stress is marked by a higher pitch and intensity accompanied by an automatic change in vowel length or rearticulation after a glottal stop preceding a single consonant and a vowel (i.e., in an open syllable). Two degrees of stress occur in CZ: primary and secondary stress. Pri-

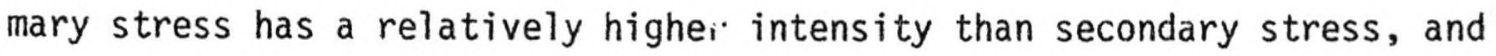
generally is higher in pitch, though the pitch difference between primary and secondary stress is sometimes indistinguishable. Primary stress occurs predominantly on the penult of a word. In the case of a phonological word which ends in a monosyllabic stem, the primary stress falls on the final monosyllabic stem rather than on the penult. When a sequence of $v_{i}$ ? $v_{j}$ occurs $\left(V_{i}=\right.$ identical vowel) as an underlying form or as a result of a $3 V_{j}$-initial suffix or stem following a $V_{j}(?)$-final stem or other preordered suffix or as a result of an umlaut ruie which causes two non-identical vowels to become identical, the primary stress passes over a penultimate second-member identical vowel and is placed upon the first identical vowel member. A word consisting of three or more syllables has in addition to primary stress, a secondary stress which occurs on the first syllable. An exception to this secondary stress assignment occurs in the case of a polysyllabic phonological word in which a monosyllabic pronominal or pre-verbal stem occurs as the first member. In this case the secondary stress passes over the nonosyllabic siem and is applied to

'Dwight Bolinger, "Accent is Predictable (If You're a Mind-Reader)," Language 48 (1972):633-44. 
the first syllable following. ' The following data iliustrate these stress patterns in various forms of single phonological words. Vowel length and rearticulation after glottal stop are shown accompanying stress when preceding a single consonant and a vowel. Primary stress will be marked by an acute accent (') and secondary stress by a grave accent (').

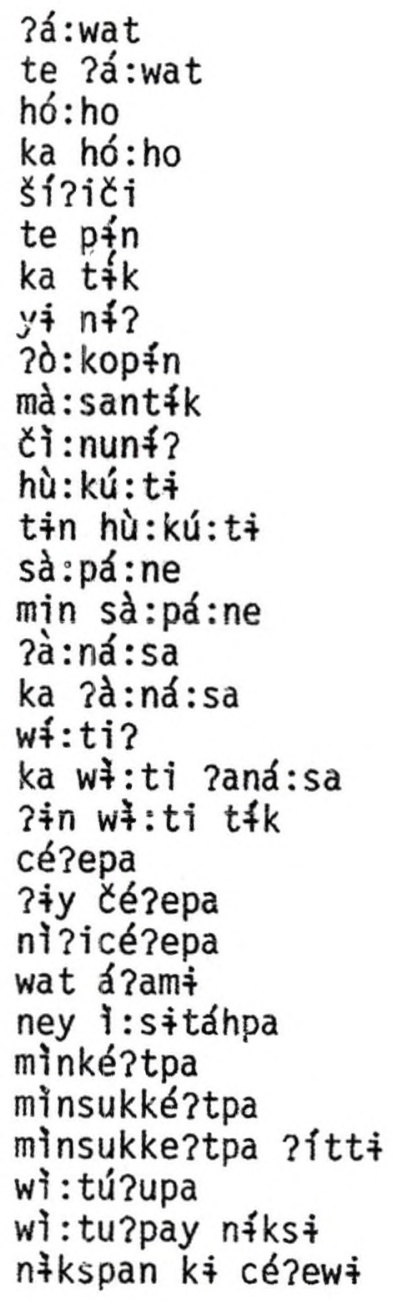

?á:wat hó: ho ka hó: ho sirici te $p+n$ y mà:santík çi:nunf? hù: kú:tż tịn hù:kú:ti sà:pá:ne min sà:pá:ne ?à:ná:sa ka ?à:ná:sa wíti?

ka wà ti ?aná:sa

?tn wat $t i$ tfk

césepa

ciy cérepa ney i:sitáhpa minké?tpa minsukké?tpa minsukke?tpa ?ítti wi: tu?pay náksi nłkspan ki cé?ewi

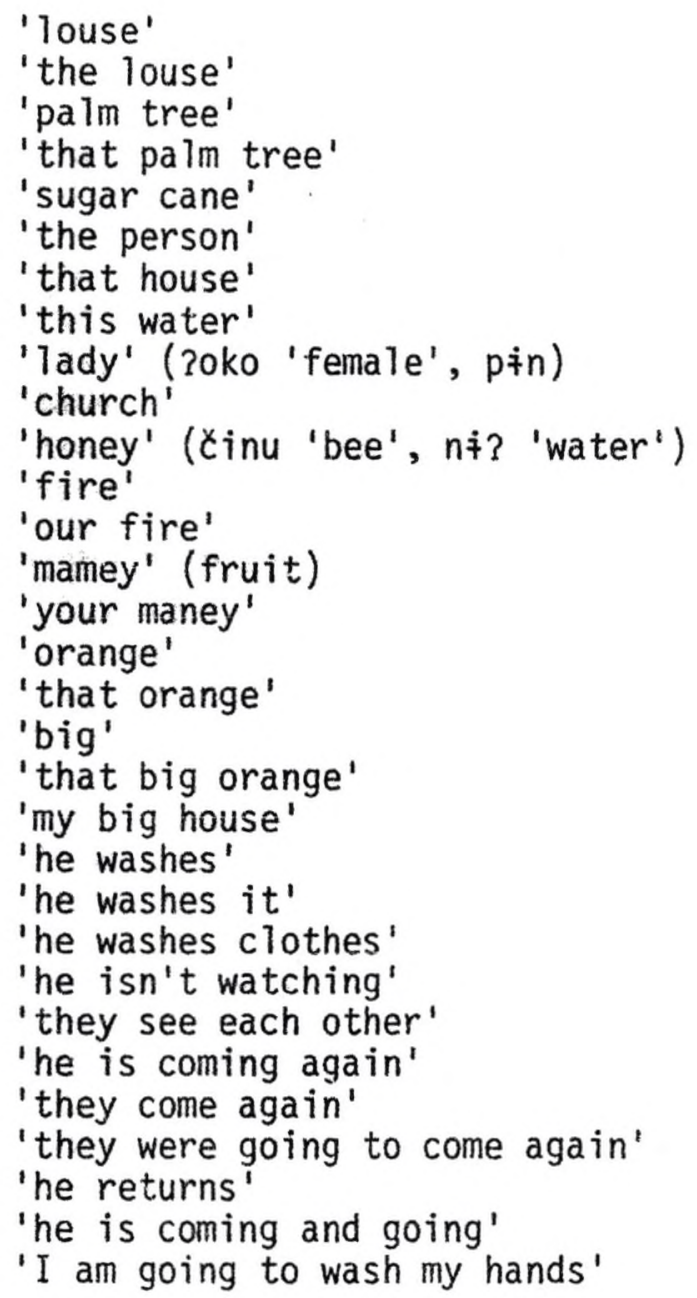

TExceptions may occur with monosyllabic prononinal stems which, for reason of focus, have gone through a transform and have been moved to the left edge of a sentence, and in effect are assigned phonological word or sentential status in themselves, thus requiring a primary stress placement. In addition, there are classes of words or phrases which appear to perform a type of discourse function, such as introducers, usually located on the left edge of a sentence, which are not consisteritly subject to regular stress patterns, often receiving no stress at a)17. 
Most Spanish loan words have retained their Spanish stress: /doktór/ 'doctor'; /myérkoles/ 'Wednesday'; /méhiko/ 'Mexico.' One exception is /kápwe/ (Spanish /kafé/) 'coffee' perhaps indicating its earlier borrowing and assimilation to the $C Z$ stress pattern. Only one widespread exception to this stress pattern in native $\mathrm{CZ}$ words has been heard: /wikití?g/ 'cicaida' which probably is onomatopoetic. Individual Zoque speakers idiolectally stress a few words not containing a final monosyllabic stem as though they did, while other $C Z$ speakers do not. For example, one informant consistently stresses the conditional marker /-pi?t/ as in the word /?otonnipi?t/ [?d:tonnipi?t] while all other speakers pronounce it as [?d:tonnf:pi?t].

For the regular stress patterns which occur in native $\mathrm{CZ}$ words, we write three stress rules: two primary stress rules, one covering monosyllabic stems, the other covering penultimate stress, and one secondary stress rule. A new symbol (\$) is being introduced which designates a stress group or phonological word boundary.

$$
\begin{array}{ll}
\text { Primary Stress } 1: & V \rightarrow\left[+ \text { stressi] } / \# C_{0} C_{0} \$\right. \\
\text { Primary Stress } 2: & \left.V_{i} \rightarrow[+ \text { stress } 1] /{ }_{2} V_{j}\right) C_{1} V C_{0} \$ \\
\text { Secondary Stress: } & V \rightarrow[+ \text { stress } 2] / \$ C_{0}\left(C_{1} V\right)_{2}
\end{array}
$$

Secondary Stress Condition: Excluding monosyllabic pronominal or pre-verbal stems

\section{Vowel Lengthening and Rearticulation}

All $\mathrm{CZ}$ vowels become long when they carry either primary or secondary stress preceding a single consonant and a vowel, if the following conscinant is not a glottal stop: 


\begin{tabular}{lcc}
\multicolumn{3}{c}{ On primary stress ('): } \\
\cline { 2 - 3 } Gioss & Incompletive & Imperative \\
'bend' & kítpa & kí:ti? \\
'kick' & képpa & ké:pa? \\
'weave' & tákpa & tá:ki? \\
'carry on back' & cámpa & cá:mi? \\
'shoot' & túhpa & tú:hi? \\
'scold' & kóspa & kó:sa?
\end{tabular}

\section{On secondary stress ('):}

$\begin{array}{ll}\text { pi:ccínpa } & \text { 'he is leaving' } \\ \text { mè:cá?an } & \text { 'two' } \\ \text { mà:santík } & \text { 'church' } \\ \text { kł̀:túkpa } & \text { 'he is passing' } \\ \text { 3ù:nu?gáhpa } & \text { 'it is getting soft' } \\ \text { wò:ko?náy } & \text { 'palmetto' (plant) }\end{array}$

Not preceding / / /:

$\begin{array}{ll}\text { ç̧ł? } & \text { 'Give it!' } \\ \text { né?a } & \text { 'wall' } \\ \text { páakak } & \text { 'sweet' } \\ \text { má?a } & \text { 'deer' } \\ \text { nú?u } & \text { 'dog' } \\ \text { nó?a } & \text { 'Burn it!' }\end{array}$

It can be added that no monosyllabic stems of the form CV occur in $\mathrm{CZ}$, thus a vowel would never be long before a word break. The above change can be captured in the following vowel lengthening rule: ${ }^{1}$

Vowe? Lengthening: $\underset{[+ \text { stress }]}{V} \rightarrow[+$ long $] /-\left\{\begin{array}{c}C \\ {[-g l o t]} \\ h\end{array}\right\} V$

Also in conjunction with stress, a primary or secondary stressed vowel preceding a glottal stop is rearticulated after the glottal stop preceding a single consonant and a vowel. Hure, as in vowel lengthening, if the consonant is a glottal stop the rearticulation does not occur. A glottal stop, however, is not apparent in this position in the surface

1 Though I would prefer to write this rule without the use of braces, the fact that glottal $/ \mathrm{h} /$ is treated as other consonants in this rule forces this description, since [-glottal] would also exclude $/ \mathrm{h} /$. An alternative would be to write a condition that $C \neq$ ? 
structure because glottal clusters are reduced by a later ordered glottal reduction rule.

\begin{tabular}{|c|c|c|c|}
\hline \multicolumn{4}{|c|}{ On primary stress $\left({ }^{\prime}\right)$ : } \\
\hline $\begin{array}{l}\text { 'climb' } \\
\text { 'ask for' } \\
\text { 'find' } \\
\text { 'disembowel } \\
\text { 'pull out ( } \\
\text { 'swallow' }\end{array}$ & ' post)' & $\begin{array}{l}\text { kí?mpa } \\
\text { cé?kpa } \\
\text { pá?tpa } \\
\text { pł?cpa } \\
\text { có?ppa } \\
\text { wú?kpa }\end{array}$ & $\begin{array}{l}\text { kí?imi? } \\
\text { cé?eka? } \\
\text { pá?ati? } \\
\text { pł?ici? } \\
\text { cóopa? } \\
\text { wú?uki? }\end{array}$ \\
\hline \multicolumn{4}{|c|}{ On secondary stress ('): } \\
\hline $\begin{array}{l}\text { ni?icé? } \\
\text { hè?epłk } \\
\text { cd?akit } \\
\text { kł?icón } \\
\text { pù?uhú: } \\
\text { kd?ocam }\end{array}$ & $\begin{array}{l}\text { epa } \\
\text { pa } \\
\text { fkho? } \\
\text { pa } \\
\text { yu? } \\
\text { lán }\end{array}$ & $\begin{array}{l}\text { 'he is washin } \\
\text { 'he is breath } \\
\text { 'under the ro } \\
\text { 'he is marryil } \\
\text { 'specie of go } \\
\text { 'brains/gizzal }\end{array}$ & othes' \\
\hline
\end{tabular}

Some examples of rearticulation being blocked by glottal stop are:

\begin{tabular}{|c|c|c|}
\hline Gloss & Incompletive & + intransitive $/-20 \mathrm{y} /$ \\
\hline $\begin{array}{l}\text { 'give' } \\
\text { 'wash' } \\
\text { 'sift' } \\
\text { 'release' }\end{array}$ & $\begin{array}{l}\text { ç?ipa } \\
\text { cé?epa } \\
\text { parapa } \\
\text { pú?upa }\end{array}$ & $\begin{array}{l}\text { cł?óypa } \\
\text { cèóypa } \\
\text { pd?óypa } \\
\text { pù?óypa }\end{array}$ \\
\hline
\end{tabular}

The existence of $/ ? /$ in the suffix /-?oy/ above can be attested by its metathesis with sonorant consonants and voicing of obstruents to be described later.

It must be noted at this point, however, that this rearticulation does not occur across word boundaries as is shown in the following exâmples:

$k i ?$

'hands'

te?y $k$ ż cé?ewi

'he washed his hands'

In the above example the /?/ of / $\mathrm{ki} ? /$ is deleted by a later ordered allophonic glottal deletion rule. This is in contrast to the verb: 


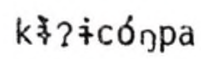

'he is marrying'

(/ki?/ 'hands' plus / ranpa/ 'he meets')

where the compounding results in a fusion as one grammatical word. In such an instance vowel rearticulation thei occurs as usual.

Other examples of non-occurrence of rearticulation across word boundaries in which similar changes occur are:

$$
\begin{aligned}
& \text { ni? } \\
& \text { te } n \text { ' hònhoysúkpa 'water' } \\
& \text { 'the water is fragrant' }
\end{aligned}
$$

ihe latter example is in contrast to:

te ni? tho múkpa 'he is falling in the water'

in which the suffix /-ho?/ 'in' follows /ni?/.

$$
\begin{array}{ll}
\text { ca? } & \text { 'rock' } \\
\text { te cd kitúkpa } & \text { 'he is passing the rock' }
\end{array}
$$

Here again the latter example is in contrast to:

te calrakitikho? 'under the rock'

where the suffix /-kitikho?/ 'under'follows/ca?/ 'rock'.

Thus this rule must be word bounded. Stanley has discussed the effects of boundaries on surrounding segments and suggests ranking a rule on the basis of the "strength" of the boundai;y which blocks it or is required in its structural description for its application; i.e., a sentence-bounded rule is sironger than a phrase-bounded rule, a phrasebounded rule is strunger than a word-boundea rule, etc. ${ }^{1}$ A rule that is sentence-bounded can therefore apply across a word or phrase boundary whereas a word-bounded rule can only apply within a word or across a morpheme boundary, which is weaker, but cannot apply across a word, phrase, or sentence boundary. In the case of Cinimalapa zoque, boundaries

1Richard Stanley, "Boundaries in Phonology," in A Festschrift for Morris Halle, eds. Stephen R. Anderson and Paul Kiparsky (New York: Rinehart \& Winston, 1973), pp. 185-206. 
play an important part in almost all the phonological rules discussed in this paper. Many $C Z$ rules have boundary markers appearing in their structural descriptions, but where a boundary marker is not explicitly written in the structural description of a rule, i.e., when a boundary blocks the application of a particular rule, it is not apparent how the rule is ranked, boundary-wise. In the absence of any better way of expressing this ranking, we will explicitly state as a condition how a rule is bound or blocked in its application where pertinent.

Based upon the data above and the boundary considerations, the following vowel rearticulation rule might be postulated:

Vowel Rearticulation: $\left.\underset{[+ \text { stress }]}{v_{i}}\right\} \rightarrow v_{i} ? v_{i} /-\{\underset{h}{[+g \text { lot }]}\} v$

Condition: Word-bounded

A glance at the vowel lengthening and vowel rearticulation rules indicates similarity not only in the conditioning environments but also in the process taking place. Other than the word-bounded condition applied to the vowel rearticulation rule the conditioning environments would be alike. It can be stated, however, that making vowel lengthening word-bounded would not affect the actual application of the rule. The only possible occurrence of a stressed vowel preceding a word boundary would be in a monosyllabic stem. Since no monosyllabic stems occur in the form CV, the sequence CV́\#CV does not exist, therefore vowel lengthening is, in effect, word-bounded.

The cunditioning environments in these two liles can therefore be made identical, and, by making the occurrence of the glottal stop optional after the vowel, the vowel rearticulation and vowel lengthening rules can be collapse "into a single vowel rearticulation and lengthening (VRL) rule: 
VRL: $\phi \rightarrow v_{i} / v_{[+ \text {stress }]}(?)-\left\{\begin{array}{c}{[-g f o t]} \\ h\end{array}\right\} V$

Condition: Word-bounded

\section{Palatalization}

In native $\mathrm{CZ}$ words the alveolars $/ \mathrm{c}, \mathrm{s}, \mathrm{n} /$ become palatal

$[\complement, \zeta, \tilde{L}]$ respectively after $/ y /$. These allophonic processes can occur across word boundaries. The palatals [¿, $[\bar{L}]$ also occur preceding an optional consonant followed by $/ \mathrm{i} /$. This latter process does not occur across word boundaries. 1

The following examples in pertinent phonetic form illustrate the occurrence of $[\chi, \zeta, \kappa]$ after $/ y /$ :

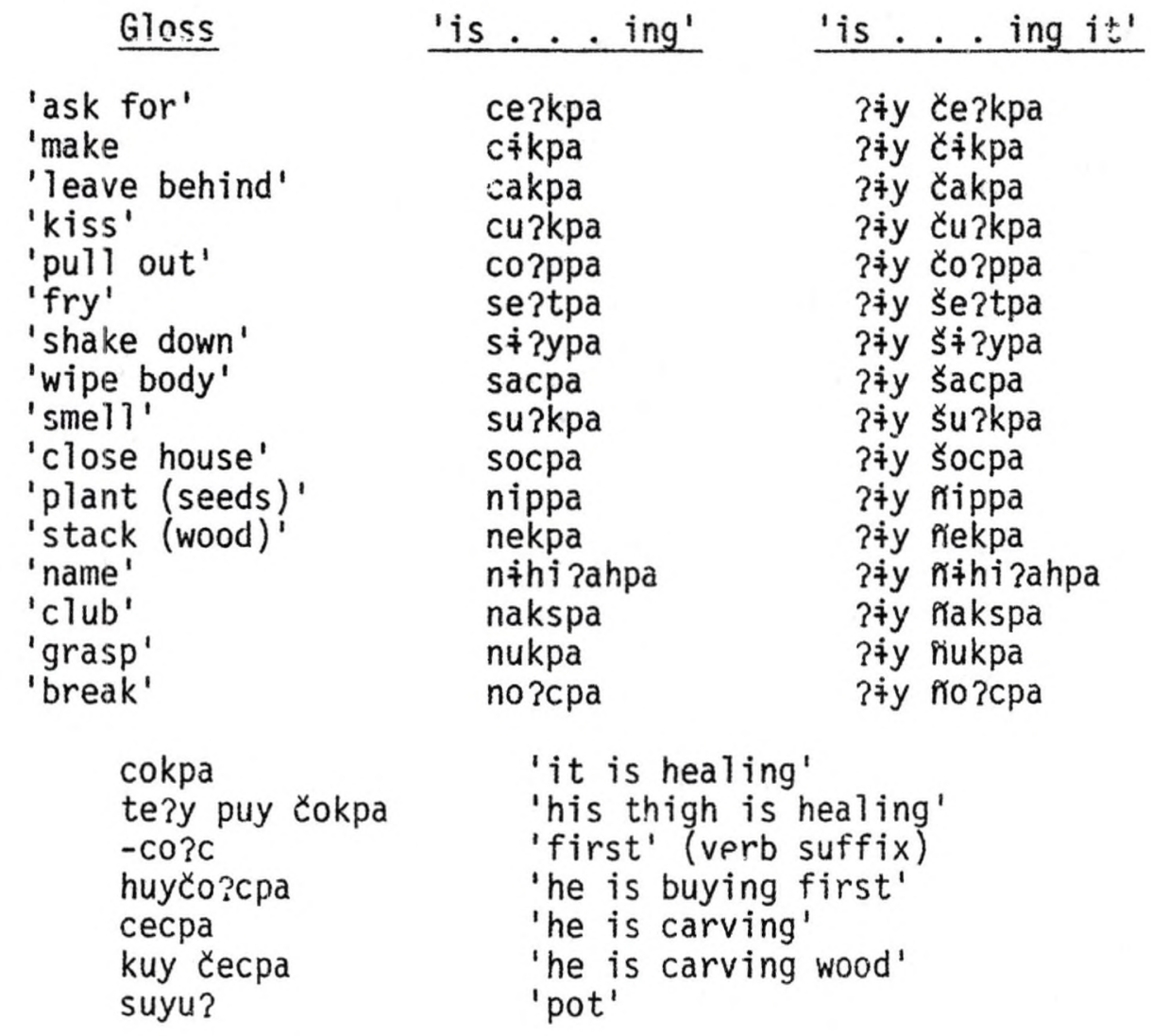

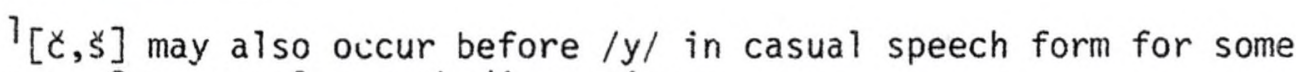
speakers. See casual speech discussion. 


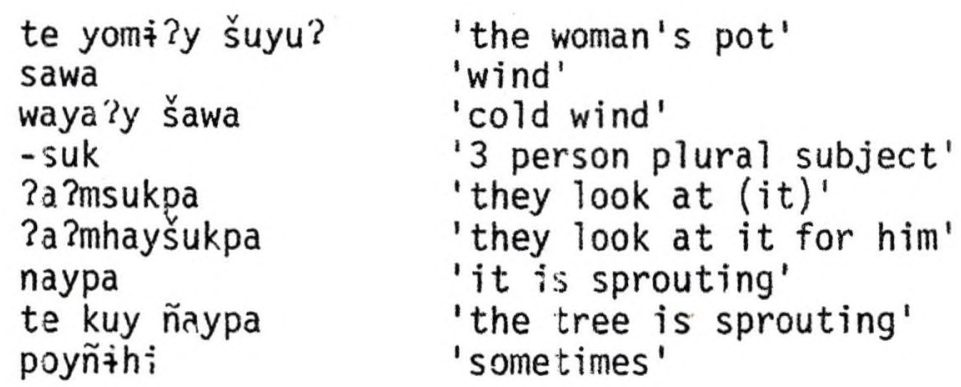

It is noteworthy that the allophone $[\tilde{n}]$ is not spoken by all $\mathrm{CZ}$ speakers, but: that it has been lost by many. It is probable therefore, that the language is in a state of change with regard to $i n / . \quad[\tilde{n}]$ may have occurred before / $i /$ also, as $[\check{c}]$ and [š] presently do, however, there is no present evidence to support this.

It has been stated that $[\dot{c}]$ and $[\dot{s}]$ also occur preceding an optional consonant followed by $/ \mathrm{i} /$, and that these changes do not occur across word boundaries. The following data in pertinent phonetic form illustrate this process:

$\begin{array}{ll}\text { meca?an } & \text { 'two' } \\ \text { mečhi? } & \text { 'the two of them' } \\ \text { ticpa } & \text { 'it is drying' } \\ \text { tiči } & \text { 'dry' } \\ \text { ti?čkin } & \text { 'castor plant' } \\ \text { čin } & \text { 'pine tree' } \\ \text { maktasan } & \text { 'four' } \\ \text { maktašhi? } & \text { 'the four of them' } \\ \text { ?iy ispa } & \text { 'he sees it' } \\ \text { ha?y isi } & \text { 'he did not see it' } \\ \text { ?išnitum } & \text { 'straight'('to see as one') } \\ \text { šis } & \text { 'meat' } \\ \text { ?ušpi } & \text { 'alligator' } \\ \text { ?uši?in } & \text { 'alittle bit' }\end{array}$

That these changes do not. occur across word boundaries can be attested by the following data: 
I_(C) $i$

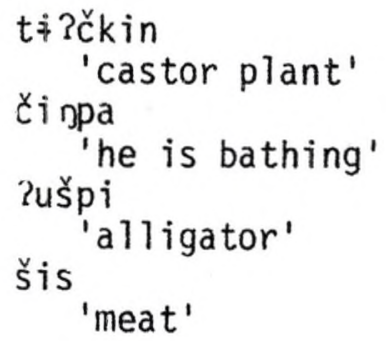

I $\#(C) i$

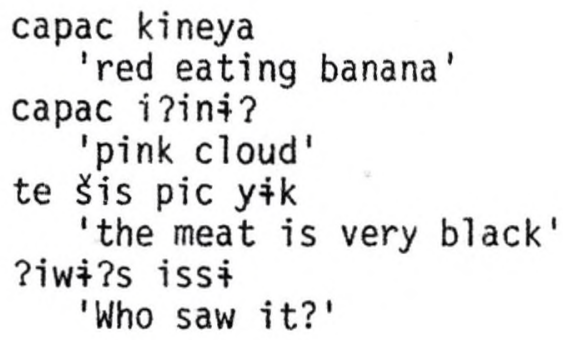

At this juncture it is worth noting that $[\check{c}, \breve{s}, \tilde{n}]$ do not occur before /y/ for most Zoque speakers (with the exception of a casual speech rule for some speakers to be covered later). This appears to be a counter-example of Neeld's hierarchy of palatalizing environments which assumes that if $/ i /$ is a palatalizing factor, then $/ y /$ is an implied palatalizing factor, since $/ y /$ is considered a higher palatalizing factor than $/ i / .^{l}$ The failure of $/ y /$ to palatalize a preceding $/ c, s, n /$ can be seen in the following illustrations:

$\begin{array}{ll}\text { sacyonpa } & \text { 'he is wiping it off' } \\ \text { te pac yukpoyyi } & \text { 'the skunk ran' } \\ \text { ?isyonpa } & \text { 'he is watching it fall' } \\ \text { te po?s yonni } & \text { 'the guayaba fell down' } \\ \text { si?nyonpa } & \text { 'pounding, he vibrates it' } \\ \text { te pin ye?cci } & \text { 'the man arrived' }\end{array}$

On the basis of the preceding data, rules showing these allophonic processes can be postulated. Since [ñ] does not appear in all the same environments as $[\check{c}]$ and $[\check{s}]$, and apparently is in a state of change, in addition to the fact that $/ c, s, n /$ do not form a natural class, it would seem more feasible to offer a separate rule for $[\tilde{n}]$. Likewise, the two different conditioning environments for $[\check{c}]$ and $[\check{s}]$ involve different boundaries or ranking, i.e., palatalization before $(C) i$ is word-bounded

IRnnald L. Neeld, "Remarks on Palatalization," in Studies in Phonology and Methodology, Working Papers in Linguistics, no. 14 (Columbus, 0.: Department of Linguistics, Ohio State University, April 1973):37-49. 
or blocked by a word boundary $(\#)$, whereas palatalization after $/ y /$ can cross word boundaries and is only blocked by a pause, or what we shall call a sentence joundary (\&). For that reason two separate rules with regard to boundaries are offered. The resulting three palatalization rules appear as follows:

$$
\begin{aligned}
& \text { Sibilant Palatalization }:[+ \text { sib }] \rightarrow[+p a l] / y \\
& \text { rondition: Sentama handart } \\
& \text { Sibilant Palatalization } 2:[+ \text { sib }]+[+p a l] / \ldots(c) i \\
& \text { Condition: Word-bounded } \\
& \text { /n/ Palatalization: } \\
& {\left[\begin{array}{l}
\text { +nas } \\
\text { tapic }
\end{array}\right] \rightarrow[+ \text { pal }] / y} \\
& \begin{array}{l}
\text { Conditions: 1) Sentence-bounded } \\
\text { 2) Optional application }
\end{array}
\end{aligned}
$$

\section{Sonorant Devoicing}

The sonorant consonants $/ m, n, 0, y /$ become voiceless after a glottal stop before pause. These are the only sonorant consonants that occur word-finally after a glottal stop in $C Z^{1}$ since /W/ does not occur in a syllable coda position, and $/ 1 /$ and $/ r /$ in the few cases where they are word-final never occur after glattal stop. The following data in pertinent phonetic form illustrate this devoicing process. Voicelessness is marked as $(\zeta)$.

$$
\begin{aligned}
& \text { mizizypana?m } \\
& \text { mizłypana?m hoho? } \\
& \text { kama?m } \\
& \text { kama?m te kuy }
\end{aligned}
$$

'he is still playing'

'he is still playing inside'

'hard'

'the tree is nard'

"The term "consonant" throughout this paper and when indicated by the symbol $\mathrm{C}$ in rule formulation is used in its broader sense to include the glides / $h, ?, y, w /$, and does not refer to the feature consonantal unless specifically stated. 


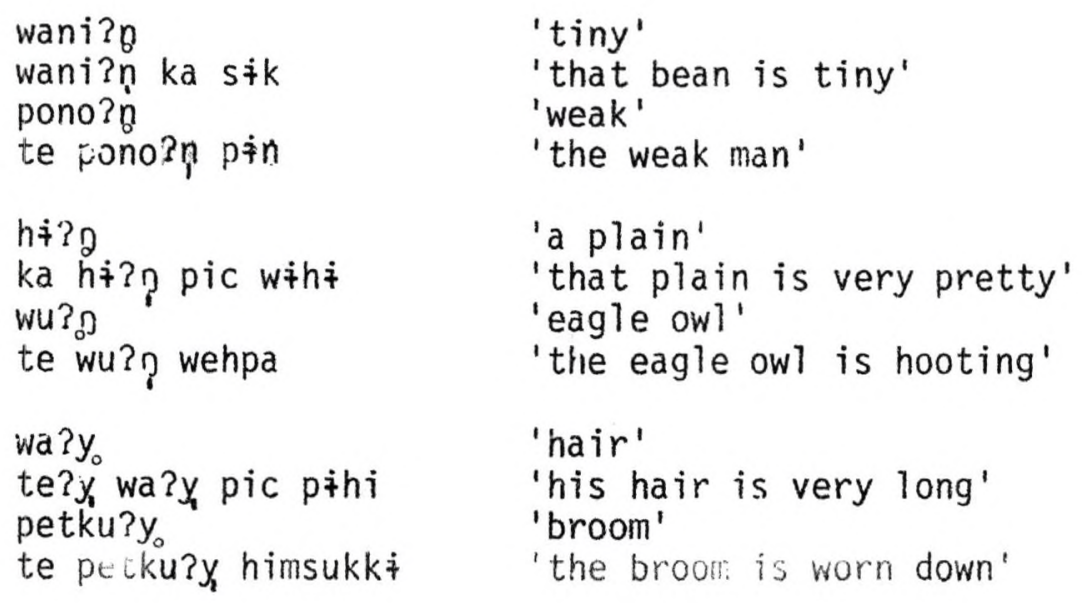

The preceding data show that these sonorants are voiced and syllabic phrase-medially, but voiceless before pause. The voiceless $\left[y_{0}\right]$ has been interpreted as $\left[y_{0}\right]$ rather than $[j]$ to distinguish it from the vowel $/ i /$ which is shown to contrast before pause in the following examples and also because the sonorant consonants used as a class upon which this rule applies is more feasible when it is realized that no $\mathrm{CZ}$ vowel becomes voiceless after glottal stop before a pause, or no vowel other than / i/ if one were to interpret this segment as [i]. Note these contrasts:

$$
\begin{array}{ll}
\text { te?y。 } & \text { 'that one's (his)' } \\
\text { te?i } & \text { 'there it is' } \\
k a ? y_{\circ} & \text { 'that yonder one's' } \\
\text { ka?i } & \text { 'there it is yonder' }
\end{array}
$$

I might also add that though phrase-medially in careful speech sonorant consonants including $/ y /$ become syllabic as described in the next section, causing the $/ y /$ to take on the quality of $[i]$, in a casual speech rule discussed later the glottal stop preceding any sonorant-initial consonant cluster or sonorant followed by a word boundary is deleted following an unstressed vowel, thereby resulting in a definitely non-syllabic/y/in contrast to / $/$ / in that same en- 
vironment where the glottal stop is not deleted in casuai speech. Note these casual speech data:

$$
\begin{array}{ll}
\text { tè? i tey tík } & \text { 'there is his house' } \\
\text { kà?i kay tík } & \text { 'there yonder is his house' }
\end{array}
$$

Considering this segment to be a voiceless $/ y /$, the following sonorant devoicing rule might then be postulated to cover this allophonic process:

$$
\text { Sonorant Devoicing: } \underset{\left[+s \cap n^{\top}\right.}{\mathrm{C}} \rightarrow[-\mathrm{vd}] / ?
$$

\section{Sonorant Syllabification}

A sonorant consonant becomes syllabic after a glottal stop before a consonant or word boundary. The syllabic consonants, including $/ y /$, will be marked as $(\underset{C}{C})$ in the following data:

$$
\begin{aligned}
& \text { kì?msúkpa } \\
& \text { nú?mmi } \\
& \text { ?à?mpa?mné?ete? } \\
& \text { hu?m nákspa } \\
& \text { nłkspa?m anmayyi } \\
& \text { 'they are climbing' } \\
& \text { 'he robbed it' } \\
& \text { 'he already is watching it also' } \\
& \text { 'Where are you going?' } \\
& \text { 'he is going to study now' } \\
& \text { téenpa } \\
& \text { hì? ñké?tti } \\
& \text { wa?n ciki } \\
& \text { póno?n pín } \\
& \text { ? in póno? ñ awin } \\
& \text { 'he is walking on his tiptoes' } \\
& \text { 'he desired it again' } \\
& \text { 'I didn't do it' } \\
& \text { 'weak man' } \\
& \text { 'my weak friend' } \\
& \text { hó?ppa } \\
& \text { t?? nk ku? y núcpa } \\
& \text { te his? o pic wán } \\
& \text { te wư? is isóypa } \\
& \text { 'he is crazy' } \\
& \text { '(the) bell is hot' } \\
& \text { 'the plain is very pretty' } \\
& \text { 'the eagle owl is alert' } \\
& \text { pł? lpa } \\
& \text { pi? Tké?tpa } \\
& \text { 'it is palsating' } \\
& \text { 'it is palsating again' } \\
& \text { tư? yy } \\
& \text { yàgạnhá? ypa } \\
& \text { te cà? y túkki } \\
& \text { te hùmu? y àksi } \\
& \text { 'it stretched' } \\
& \text { 'he is sounding it' } \\
& \text { 'he cut the rope' } \\
& \text { 'the plum split open' }
\end{aligned}
$$


It can bi noted that the sonorants $/ r /$ and $/ \mathrm{w} /$ are not ircluded in the data above because / $/ \mathrm{W}$ never occurs preceding another consonant nor in a syllable coda position, and $/ r /$ never occurs after a glottal stop preceding a consonant.

Based on these data a sonorant syllabification rule can be written:

$$
\text { Sonorant Syllabification: } \underset{[+ \text { son }]}{C} \rightarrow[+ \text { syll }] / ?\left\{\begin{array}{c}
C \\
f f
\end{array}\right\}
$$

Conditicn: Sentence-bounded

\section{Glottal Metathesis}

A suffix-initial lottal stop inetathesizes with stem-final sonorant consonants. The only voiced consonants which occur stem-finally in native $\mathrm{CZ}$ words are the sonorants $/ \mathrm{m}, \mathrm{n}, \mathrm{D}, r, y /$ (/r/ occurs finally in only one word: /nakstir/ 'sling'). When including Spanish loan words, glottal stop also methesizes with $/ 1 /$. $/ \mathrm{w} /$ does not occur in syllable coda position in $\mathrm{CZ}$. The following data show methathesis:

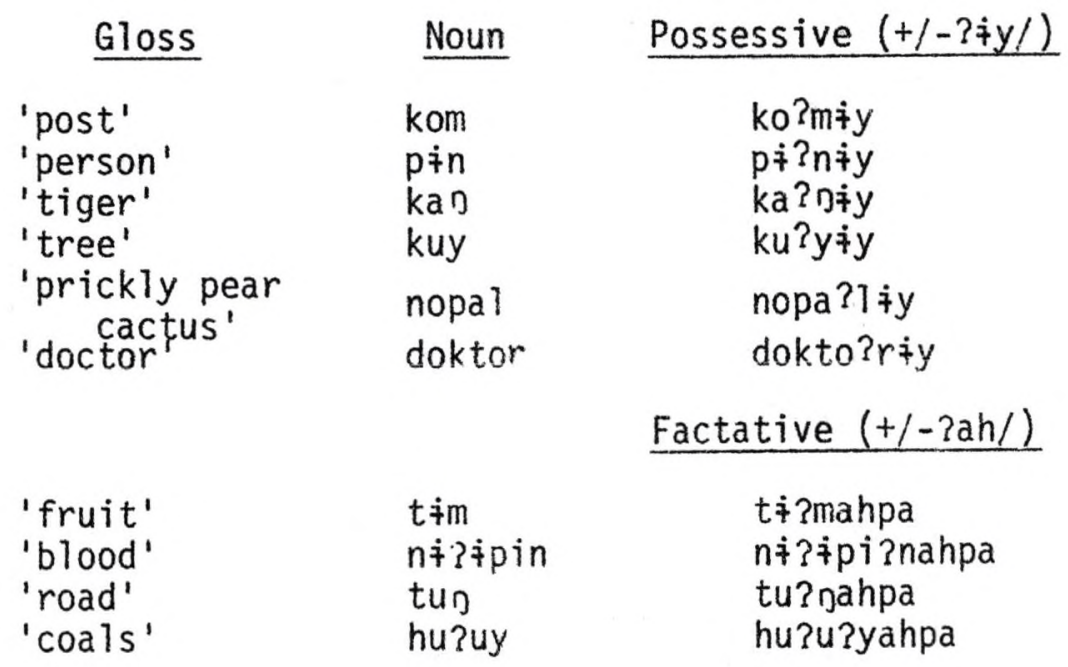




\section{Transitive Intransitive $(+/-$-20y $/)$}

'fan (fire)' yempa

'strip bark' wonpa

'meet' conpa

'count' maypa

ye?moypa

wo?noypa

co? noypa

ma?yoypa

Miscellaneous occurrences

\begin{tabular}{|c|c|}
\hline $\begin{array}{l}\text { cu?an } \\
\text { cu?a?nam }\end{array}$ & $\begin{array}{l}\text { 'late' } \\
\text { 'it is late already' }(+/- \text { ?am/ 'already') }\end{array}$ \\
\hline $\begin{array}{l}\text { pin } \\
\text { te pi?nis iy ki?ssi } \\
\qquad(/ p i n / \text { plus }\end{array}$ & $\begin{array}{l}\text { 'person/man' } \\
\text { 'the man ate it' } \\
\text { /-?is/ 'subject marker') }\end{array}$ \\
\hline
\end{tabular}

boundary, thus it is word-bounded. The following glottal metathes is

rule describes this process:

Glottal Metathesis: $\begin{gathered}\mathrm{C} \\ {\left[\begin{array}{c}+\mathrm{son} \\ 1\end{array}\right]}\end{gathered} \quad \begin{array}{llll}2 & 3\end{array}$

Condition: Word-bounded

One aspect which must be considered is that the result of the glottal metathesis would feed the vowel rearticulation rule, causing the vowel to be rearticulated after the glottal stop, which does not occur in the case of glottal metathesis. To prevent this, it is necessary to order the vowel rearticulation and lengthening rule before the glottal motathesis rule. This ordering has been a deciding factor in considering the glottal metathesis rule to be an allophonic process rather than morphophonemic. Tnis is considered to be a simpler explanation than positing an additional rule to delete a vowel created bv vowel rearticulation. This ordering relationship can be seen in the following derivations: 
'he fans (fire)' 'he is fanning' 'Fan!'

$\begin{array}{llll}\text { Underlying: } & \text { \&yem+pa\& } & \text { \&yem+?oy+pa\& } & \text { \&yem+?oy+?\& } \\ \text { Other rules: } & - & - & \text { \&yem?0?\& } \\ \text { Stress: } & \text { yémpa } & \text { yèm?óypa } & \text { yém?o? } \\ \text { VRL: } & - & - & - \\ \text { ? Met: } & - & \text { yè?móypa } & \text { yé?mo? } \\ \text { Surface: } & \text { yémpa } & \text { yè?móypa } & \text { yé?mo? }\end{array}$

If however, the glottal metathesis rule were ordered before the vowel rearticulation and lengthening rule, the following derivation would result in an unacceptable output:

$\begin{array}{llll}\text { Underlying: } & \text { \&yem+pa\& } & \text { \&yem+?oy+pa\& } & \text { \&yem+?oy+?\& } \\ \text { Other rules: } & - & - & \text { \&yem?o?\& } \\ \text { Stress: } & \text { yémpa } & \text { yèm?óypa } & \text { yém?o? } \\ \text { ? Met: } & - & \text { yè?móypa } & \text { yé?mo? } \\ \text { VRL: } & --- & \text { yè?emóypa } & \text { yé?emo? } \\ \text { Surface: } & \text { yémpa } & \text { *yè?emóypa* } & \text { *yé?emo?* }\end{array}$

Obstruent Voicing

Stem-final voiceless cbstruents become voiced preceding glottal stop-initial suffixes. When this occurs, the suffix-initial glottal stop voices the preceding voiceless obstruent and then is deleted. If the obstruent is preceded by a stressed vowel and not a consonant nor glottal stop, the preceding vowel receives intermediate length, here symbolized as $\mathrm{V} \cdot$, which is longer than a short vowel but shorter than a full long vowel produced by the previously discussed vowel rearticulation and lengthening rule. The one exception to the obstruent voicing is $/ \mathrm{s} /$. However, in the above environment, a vowel preceding 
/s/ has the same intermediate length that vowels possess which precede the other obstruents voiced by this process. In addition, in the case of a stressed vowel and glottal stop preceding an $/ \mathrm{s} /$ which is in turn followed by a glottal stop-initial suffix, there is no rearticulation of the vowel preceding the $/ \mathrm{s} /$, which is also absent before the other obstruents which become voiced. Because of these factors, it appears that the $/ \mathrm{s} /$ in these environments is acting as a $[z]$, since voicing follows intermediate vowel length. A separate rule, therefore, is being introduced to change an intermediate [z] to $/ \mathrm{s} /$. The following examples show the pertinent data in phonetic form:

\begin{tabular}{|c|c|c|}
\hline Gloss & Incompletive & Imperative \\
\hline $\begin{array}{l}\text { 'lash' } \\
\text { 'lash together' }\end{array}$ & $\begin{array}{l}\text { wátpa } \\
\text { wà } \cdot \text { df́ypa }\end{array}$ & $\begin{array}{l}\text { wá:tị? } \\
\text { wá.dì? }\end{array}$ \\
\hline $\begin{array}{l}\text { 'sow' (trans.) } \\
\text { 'be sowing' }\end{array}$ & $\begin{array}{l}\text { púppa } \\
\text { pù·bóypa }\end{array}$ & $\begin{array}{l}\text { pú:pi?? } \\
\text { pú·bo? }\end{array}$ \\
\hline $\begin{array}{l}\text { 'drink' } \\
\text { 'drink posol' }\end{array}$ & $\begin{array}{l}\text { ?úkpa } \\
\text { ?ù·góypa }\end{array}$ & 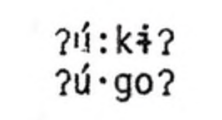 \\
\hline $\begin{array}{l}\text { 'break' (trans.) } \\
\text { 'be breaking' }\end{array}$ & $\begin{array}{l}\text { nó?cpa } \\
\text { ndे?zбуypa }\end{array}$ & $\begin{array}{l}\text { nó?oca? } \\
\text { nó?zo? }\end{array}$ \\
\hline $\begin{array}{l}\text { 'know' (trans.) } \\
\text { 'be knowing' }\end{array}$ & $\begin{array}{l}\text { múspa } \\
\text { mù·sóypa }\end{array}$ & $\begin{array}{l}\text { mú:si?? } \\
\text { mú·so? }\end{array}$ \\
\hline $\begin{array}{l}\text { 'eat' (trans.) } \\
\text { 'be eating' }\end{array}$ & $\begin{array}{l}\text { kł? spa } \\
\text { kł?sóypa }\end{array}$ & $\begin{array}{l}\text { kf?assi? } \\
\text { kf?so? }\end{array}$ \\
\hline
\end{tabular}

The fact that the two suffixes /-?iy/ and /-?oy/ used above are glottal stop-initial can be attested when these same suffixes follow a stem-final sonorant consonant in which case the glottal stop metathesizes with the sonorant consonant. As in the case with the glottal metathesis rule, the processes above do not occur across a word boundary in careful speech.

The above processes can be captured in three ordered rules: an 
obstruent volcing ruie, an intermediate vowel lengthering rule, and a $z \rightarrow$ s rule:

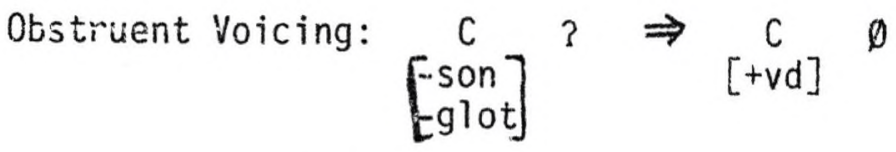

Condition: Word-bounded

Intermed. Vowel Length: $\underset{[+ \text { stress }]}{V} \rightarrow v \cdot /-\underset{c}{C}+v$

Condition: Word-bounded

Changing any intermediate [z] to /s/ would be simply:

$$
z \rightarrow s: \quad z \rightarrow s
$$

These three rules plus the previous vowel rearticulation and lengthening rule would have to be ordered as follows:

(1) Vowel Rearticulation and Lengthening (VRL)

(2) Obstruent Voicing ( $\mathrm{Ob} \mathrm{Vg}$ )

(3) Intermediate Vowel Lengthening (IVL)

(4) $z \rightarrow s$

The following derivations show the effect of the above ordered rutes:

\begin{tabular}{|c|c|c|c|c|}
\hline \multirow[b]{2}{*}{$\begin{array}{l}\text { UF: } \\
\text { Other: } \\
\text { Stress: } \\
\text { VRL: } \\
\text { Ob Vg: } \\
\text { IVL: } \\
\text { Other: } \\
\text { Surf: }\end{array}$} & 'he drinks' & 'Drink!' & \multicolumn{2}{|c|}{ 'he drinks posol' } \\
\hline & $\begin{array}{l}\text { \& ?uk+pa\& } \\
--- \\
\text { ?úkpa } \\
--- \\
--- \\
-\overline{-} \\
\text { ?úk } \\
\text { ?úk ha } \\
\text { ?ua }\end{array}$ & $\begin{array}{l}\text { \&?uk+?\& } \\
\text { \& ?uki?\& } \\
\text { ?ú:ki? } \\
\text { ?ú:ki? } \\
--- \\
--- \\
-\overline{-} \\
\text { ?úkit? }\end{array}$ & \multicolumn{2}{|c|}{$\begin{array}{l}\text { \& ?uk+?oy+pa\& } \\
-\overline{-}- \\
\text { ?ùk?óypa } \\
-\overline{-}- \\
\text { ?ùgóypa } \\
\text { ?ù·góypa } \\
-\overline{-}- \\
\text { ?ù·góypa }\end{array}$} \\
\hline & 'he eats it' & 'Eât it:' & 'he eats' & 'Eat!' \\
\hline $\begin{array}{l}\text { UF: } \\
\text { 0ther: } \\
\text { VRL: } \\
\text { Ob Vg: } \\
\text { IVL: } \\
z \rightarrow \text { s: } \\
\text { Surf: }\end{array}$ & $\begin{array}{l}\& k \dot{q}\} s+p a \& \\
k \neq ? s p a \\
--- \\
--- \\
--- \\
-\overline{-}- \\
\text { kq?spa }\end{array}$ & 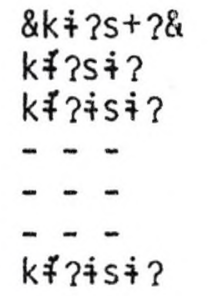 & 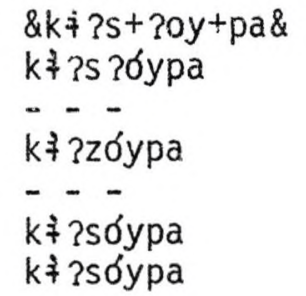 & 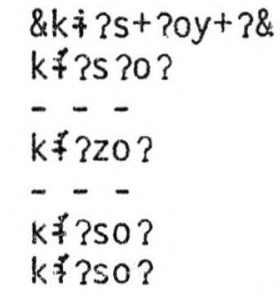 \\
\hline
\end{tabular}




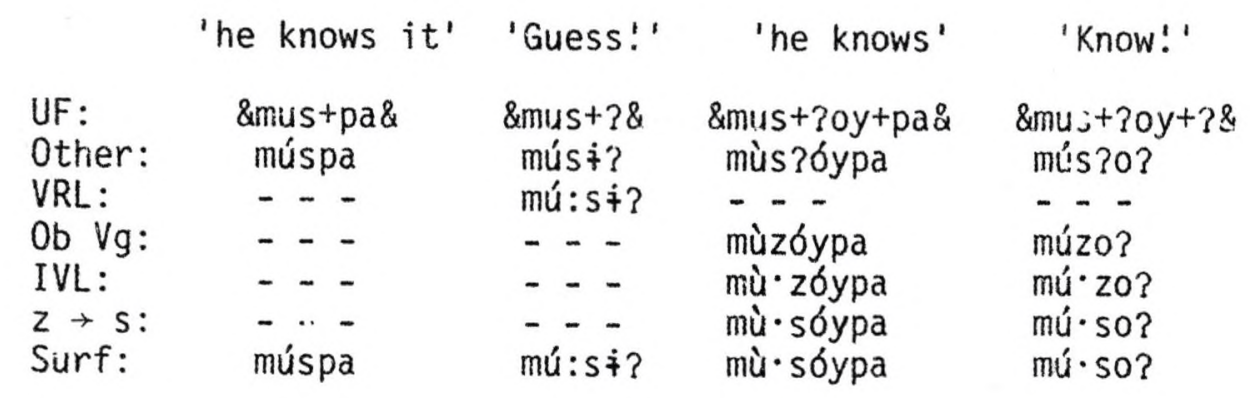

Identical Vowel Deletion

In the underlying sequence of $V_{i}(?) ? V_{i}[$ nas ] appearing in a suffix or at a stem-suffix juncture, the identical vowel following the glottal stop is deleted when the nasal is followed by a word boundary or what we will call a clitic boundary and a consonant. ' This deletion does not occur, however, at the juncture of a monosyllabic stem and a following clitic. For example, when suffixes/?am/ perfective) and / 2aj/ (perceptional) follow an /a(?)/-final non-monosyllabic stem or suffix but followed by a word or clitic boundary plus consonant, $/ a ? m /$ and $/ a ? b /$ result respectively. Note that this rule has an opposite effect of the vowel rearticulation and lengthening rule, but appears to be governed by a similar principle. The VRL rule begins with an underlying $V$ ? sequence and rearticulates the vowel when stressed preceding $\mathrm{CV}$, but is blocked by a consonant cluster. The present

IA clitic boundary, here symbolized as $(=)$, encloses a small distinct class of suffixes, which for the most part can be affixed to most noun, verb, adjective or adverb stems, or other suffixes of these stems. With regard to the boundary hierarchy, it is stronger than a morpheme boundary, but weaker than a word boundary. Any wordbounded rule whose conditioning environment is met can be applied across it. A clitic boundary's major influence is in relation to the morphophonemic vowel epenthesis rule described ir the next chapter, however, due to its far-ranging occurrence, the presently discussed rule is affected by it. Positing additional boundary markers to distinguish special morpheme classes has precedence in Stanley, "Boundaries in Phonology" previously cited. 
ruie, however, begins with a sequence of $V_{j}(?) ? V_{j}$ and reduces it to ? preceding a cluster of nasal plus consonant. Note in the following data that the vowel deletion occurs whether the preceding ident.ical vowel is stressed or unstressed, therefore stress is not pertinent in the conditioning environmeni.?

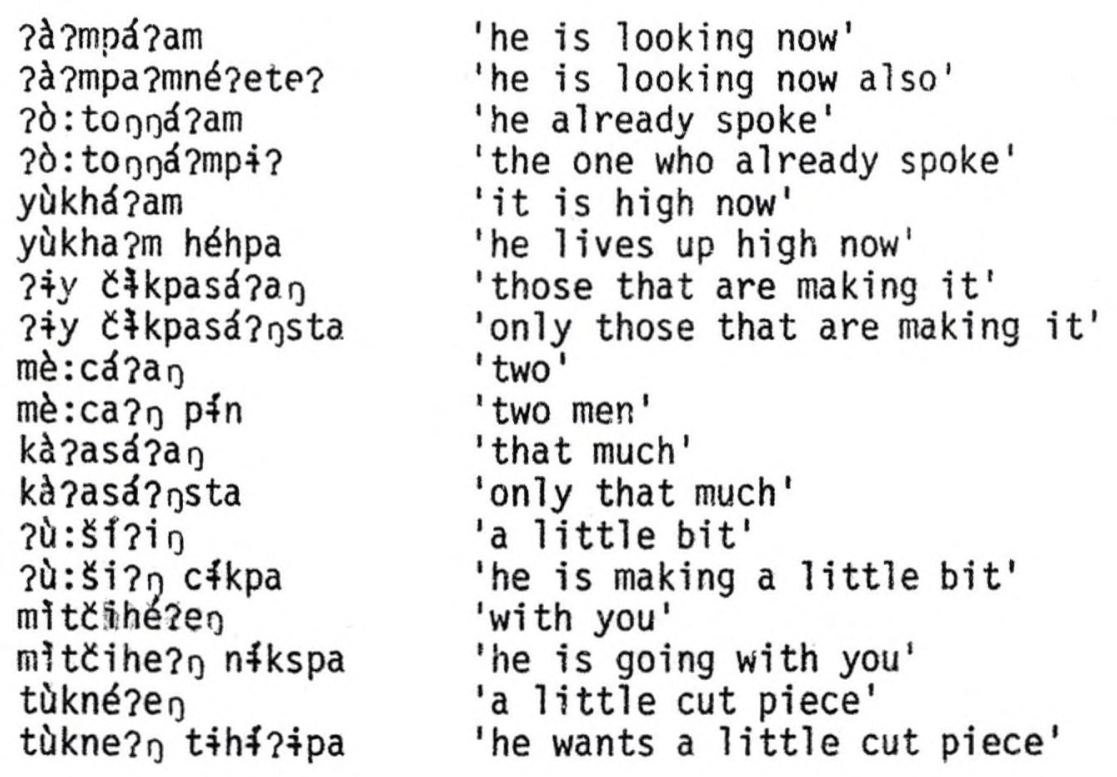

The non-occurrence of this deletion at the juncture of a monosyllabic stem and a following clitic can be illustrated by the following examples:
ká?àn
ká?ansta
'death'
'only death'

The word /ka?ag/ 'death' above consists of the monosyllabic stem /ka?h-/ 'die' followed by the clitic/=an/ (perceptional). Morphophonemic $/ \mathrm{h} /$ deletion and glottal reduction result in the form give

From these data, the following identical vowel deletion rule

Those clitic-bounded forms included in these data are: / ?am/ 'already/now', /ne?ete?/ 'also', /pit/ 'the one that is', /sa?a/ 'those that are', ista/ 'only.' 
might be written as sentence-bounded to avoid braces in the choice of word or clitic boundary in the structural description:

Identical Vowel Deletion: $\left.V_{i} \rightarrow \emptyset ! C_{1} V C_{1} V_{i}\right]_{[+ \text {nas }]}^{C}=c$

Condition: Sentence-bounded

\section{/i/ Deletion}

An / i/ is deleted following an unstressed vowel and glottal stop preceding $/ \mathrm{s} /$. This appears to be undergoing a process similar to identical vowel deletion, but with the exception of being conditioned by stress, or the lack of it, and of rot requiring an identical vower nor consonant cluster in the structural description. Because of these distinctions, and the fact that $/ \mathrm{s} /$ and nasals do not form a natural class, the two rules cannot be collapsed into one. This rule is limited in its application to the subject marker suffix/2is/, since there are no other instances with this sequence following an unstressed vowel. Note the following data which shows/-?is/ after both stressed and unstressed vowels:

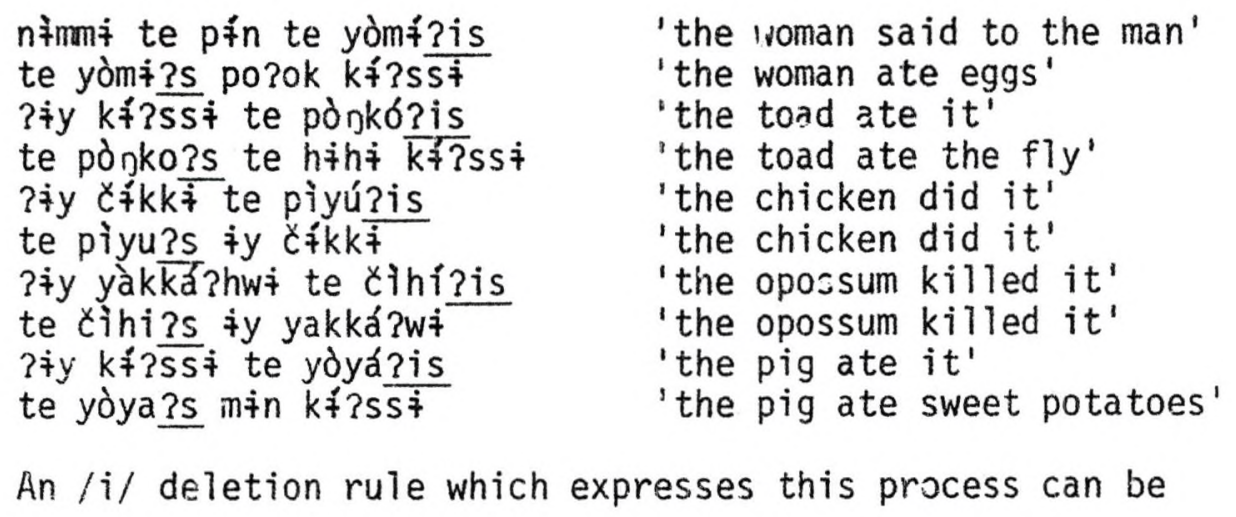

written as:

/i/ Deletion: $i \rightarrow \emptyset$ / $\underset{[\text {-stress }]}{V}$ ? - s

Condition: Word-bounded 


\section{1+1 Deletion}

The $/ \dot{f} /$ in the possessive suffix /?iy/ is deleted when it is unstressed following a $V(?)$-final stem. It should be noted that there are several different morphemes of the form / ?iy/ in Zoque. For example, /2iy/ may be a possessive marker, a third person pronoun, a verb suffix meaning to generalize an action, or another suffix when, when affixed to a noun or adjective stem creates a verb form meaning 'to have' the noun or adjectival quality of the stem preceding it. This last suffix could possibly be linked with the possessive form since 'to have' something is akin to something 'belonging to' someone. This deletion referred to, however, occurs only in the case of the possessive form. Note the following data:

\begin{tabular}{cl}
\multicolumn{1}{c}{ Gloss } & \\
'opossum' & cíhi? \\
'scorpion' & kákwe? \\
'that one' & té?pis? \\
'mother' & máma? \\
'toad' & pónko? \\
'badger' & cíku \\
'husband' & háya
\end{tabular}

\section{$+\mid 2+y / 1$. 's house' $^{\prime}$}

tihi?y ták $k a k w e ? y$ tzk tè?pi?y tik màma?y $t$ t $k$ pònko?y tfk ciku?y tfk hàa?y $t \mathfrak{k}$

Following a consonant-final stem, this deletion does not occur:

$\begin{array}{lll}\text { 'skunk' } & \text { pac } & \text { paziy } \\ \text { 'house' } & \text { tik } & \text { tigiy } \\ \text { 'earth' } & \text { nas } & \text { nasiy } \\ \text { 'tiger' } & \text { ka } & \text { ka? jiy } \\ \text { 'tree' } & \text { kuy } & \text { ku?yiy }\end{array}$

Nor does it occur when the $/ \dot{q} /$ in question is stressed:

\begin{tabular}{|c|c|c|}
\hline Gloss & & ?/ 'It's \\
\hline $\begin{array}{l}\text { 'vul ture' } \\
\text { ' toad' } \\
\text { 'mother' } \\
\text { 'scorpion' } \\
\text { 'badger' }\end{array}$ & $\begin{array}{l}\text { wi?iši? } \\
\text { ponko? } \\
\text { mama? } \\
\text { kakwe? } \\
\text { ciku }\end{array}$ & $\begin{array}{l}\text { wì?išinfyhe? } \\
\text { pdnko?fyhe? } \\
\text { mama? fyhe? } \\
\text { kàkwe?qyne? } \\
\text { ciku?fyhe? }\end{array}$ \\
\hline
\end{tabular}


The above data supports a rule which could be written as follows with its application limited to the possessive marker ard avoiding the other / ?iy/ morphemes. The optional stem-final glottal stop need not be included in the structural description since it would be deleted by a pre-ordered glottal reduction rule to be described next.

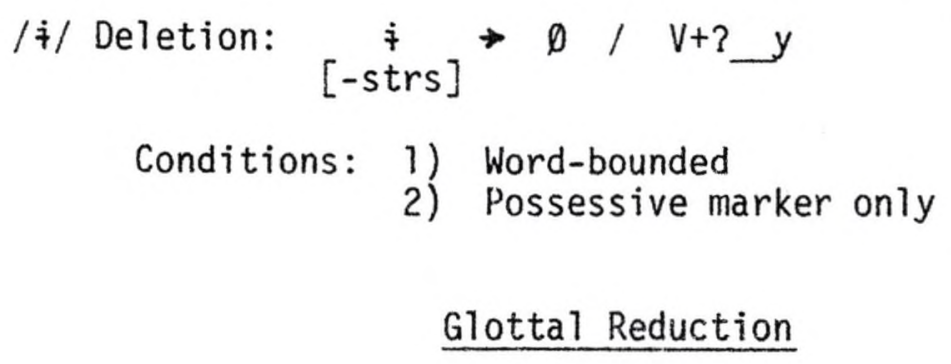

\section{Glottal Reduction}

A glottal stop cluster is reduced to one glottal stop. A cluster may occur as the result of a/?/-initial stem or suffix following a /2/-final stem or affix. In addition, certain rules, such as glottal metathesis and morphophonemic $/ \mathrm{h} /$ deletion, feed glottal reduction. In view of the structural descriptions of other rules, such as the $/ \dot{q} /$ deletion rule above, the left-most glottal stop in a cluster is deleted. A rule describing this process can be written simply as:

Glottal Reduction: $? ? \Rightarrow$ ?

The following derivations show glottal reduction in an ordering relationship with other rules.

'he is mounting'

UF:

h-Del:

Stress:

?-Met:

?-Red:

Surf:
\& $k i ? m+3 o y+p a \&$

kìm?óypa

kì?móypa

kì ?móypa

kì ?móypa 'he is killing'

\&yak+ka?h+2oy+pa\& \&yak+ka?+?oy+pa\& yàkka??óypa yàkkà ?óypa yàkka?óypa 


\section{Glottal Deletion}

A glottal stop is deleted continguous to a consonant across a word boundary. Specifically, a word-initial glottal stop is deleted following a con'onant-final word, and conversely, a word-final glottal stop is deleted preceding a consonant-initial word. Note the following data:

$(? \# C)$ :

$n \dot{q} ?$

ni pikpa

te?

te $n \dot{q}$ tigiypa

?unne?

te ?unne kabayu?

$\mathrm{ka}$ ?

ka kabayu si?tpa

cihi?

te Cini cinayyi

?unne hallon

ca?

ka ca woyi?iwi

witi?

te witi ni? 'water'

'he is getting water'

'the/ that'

'the water is entering'

'little'

'the lit.tle horse'

'that yonder one'

'he bridles that horse'

'opossum'

'the opossum sat down'

'little boy'

'rock'

'that rock rolled over'

'big'

'the big river'

(C\#?): 'he is studying'

'that one is studying'

'he has'

'he has a fence'

'he shells'

'he shells beans'

'(he) is alert'

'you are alert'

'he looks'

'he looks at the meat'

'he drinks'

'the cow drinks'

'orange'

'sour orange'

'he held his breath'

'the man held his breath'

'he is resting'

'that tiger is resting '

'place'

'cold place' 
Based on the preceding data, a single glottal deletion rule combining both environments of this mirror image process might be written as:

Glottal Deletion: $\quad ? \rightarrow \emptyset /\left\{\begin{array}{l}V \# C \\ C \#-V\}\end{array}\right.$

It could possibly be argued on the basis of the above data that the $/$ ? could be epenthetic word-initial following a sentence boundary or vowe?-final word across a word-boundary. I have analyzed the /?/ as underlying, however, because in casual speech it metathesizes with word-final sonorant consonants and voices obstruents across a word boundary, thereby paralleling the careful speech glottal metathesis and obstruent voicing rules excepting their word-bounded condition.

\section{/p/ Lenition}

The bilabial voiceless obstruent /p/ becomes fricative or lenis [в] preceding a / w/ which is followed bj an unstressed vowel. There are three commonly used words in native $\mathrm{CZ}$ in which this process occurs, all three basically of the same form:

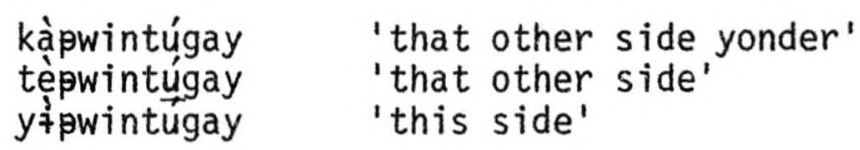

Across word boundaries the $/ p /$ does not become [p] before $/ w /$ because the following vowel is stressed in all data available:

$$
\begin{array}{ll}
\text { ká?p wìntígi? } & \text { 'Enter before him!' } \\
\text { te?p wéhpa } & \text { 'He is yelling' }
\end{array}
$$

By compounding /p/-final and / w/-initial stems it is possible to show the factor of stress in this process:

$$
\begin{array}{ll}
\text { hùpwó?tpa } & \text { 'He walks holding hands' } \\
\text { hưpwo?tsúkpa } & \text { 'They walk holding hands' }
\end{array}
$$


Since this process has only been found to cccur within word boundaries, the following /p/ lenition rule will be so conditioned:

/p/ Lenition: $p \rightarrow \beta /-W \underset{[-s t r]}{V}$

Condition: Word-bounded

\section{/h/ Friction}

Voiceless glottal /h/ receives a greater degree of friction or breathiness, here symbolized as $[h]$, when occurring word-final or preceding a consonant. [h] also fluctuates with $[h]$ preceding non-back high or mid vowels $(i, e, i)$ :

\begin{tabular}{|c|c|}
\hline sah & 'wing' \\
\hline pohn & 'vine' \\
\hline pup̣ & 'sperm/seed' \\
\hline hahppa & 'he has perspiration odor' \\
\hline huhpa & 'she is laying an egg' \\
\hline kohppa & 'he is sticking it' \\
\hline 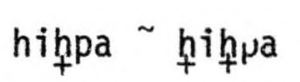 & 'he is blowing his nose' \\
\hline heḥpa $\underset{+}{\text { hehppa }}$ & 'he lives' \\
\hline ?ịppa & 'he is holding his breath' \\
\hline hiура híypa & 'he is crying' \\
\hline
\end{tabular}

These changes might be captured in the following /h/-friction rules, the second of which is optional:

$$
\begin{aligned}
& / h / \text { Friction }_{1}: h \rightarrow \not h /-\left\{\begin{array}{l}
\# \\
C
\end{array}\right\} \\
& / h / \text { Friction }: h+h /-\left[\begin{array}{c}
V \\
+h i \\
+m i d \\
-b k
\end{array}\right]
\end{aligned}
$$

Condition: Optional 


\section{Voiceless and Voiced Release}

A voiceless release or aspiration occurs between a voiceless nonglottal stop and a following heterorganic stop or affricate or pause. A voiced open transition occurs between a voiceless non-glottal stop and a heterorganic nasal. In casual speech, this transition or voiced release also occurs between a voiced stop and heterorganic nasal. No consonant with the exception of glottal stop occurs before velar $/ \mathrm{g} /$, therefore $/ g /$ is not included in the following data which illustrate these releases:

Voiceless release or aspiration:

\begin{tabular}{|c|c|}
\hline képpa & 'he kicks' \\
\hline nìp ${ }^{h}$ túk $^{h}$ pa & 'he is finishing planting' \\
\hline nip ${ }^{h_{k E}} t^{h_{p a}}$ & 'he is planting again' \\
\hline niph ${ }^{h} \sigma ? c p a$ & 'he is planting first' \\
\hline te?ph cínpa & 'he is bathing' \\
\hline$k o t^{h_{p a}}$ & 'he is guarding' \\
\hline kótti & 'he guarded' \\
\hline mòt ${ }^{h_{k}}$ ? $t^{h_{p a}}$ & 'he is mixing them again' \\
\hline pł̀?tcó?cpa & 'he will find it first' \\
\hline yé?cpa & 'he is arriving' \\
\hline còcké?t $\mathrm{h}_{\mathrm{pa}}$ & 'he sp?it it again' \\
\hline cèctúkki & 'he firished carving' \\
\hline húcci i ${ }^{1}$ & 'he cut it in one blow' \\
\hline yú\}Ł̌̌i? & 'tiny (seed-1ike)' \\
\hline$p^{f} k^{h} p a$ & 'he is getting it' \\
\hline
\end{tabular}

${ }^{1}$ No release occurs between homorganic consonants, thus $/ \mathrm{cc} /$ is realized phonetically as [tts] and likewise / $\check{c} /$ as [tt's]. 


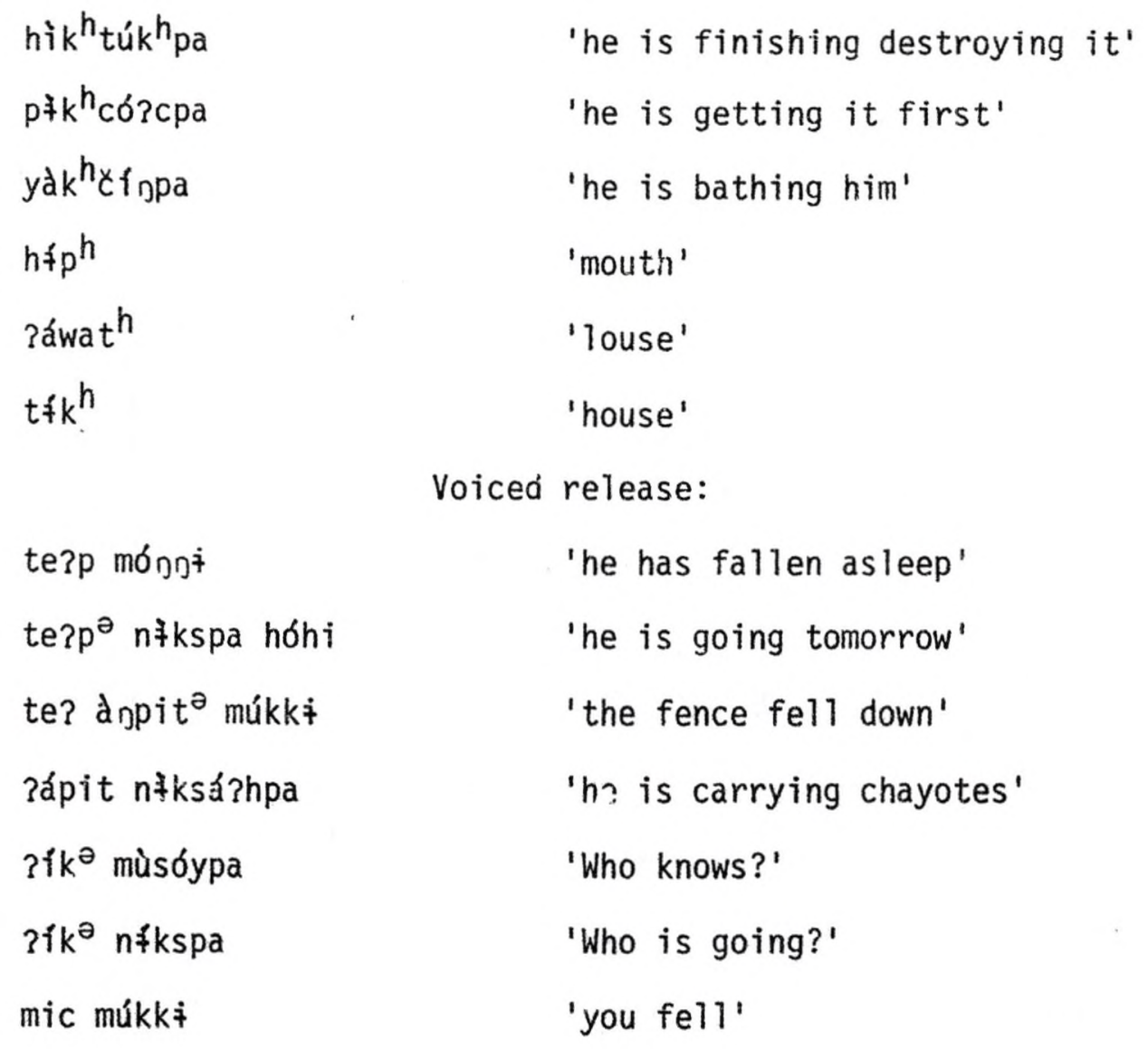

Casual speech voiced release:

te? $\mathrm{b}^{\curvearrowright}$ nákspa

'he is going'

te? ánpid múkki

'the fence fell down'

yàg ${ }^{2}$ ma nnáypa

'he is standing it up'

?ig $\mathrm{g}^{\ominus} \mathrm{n}$ kspa

'Who is going?'

Based on the preceding data, a voiceless release rule can be formulated as follows:

Voiceless Release: $\emptyset \rightarrow h /\left[\begin{array}{l}- \text { son } \\ - \text { glot } \\ - \text { sib } \\ \alpha \mathrm{F}\end{array}\right]-\left\{\left[\begin{array}{c}\& \\ + \text { cons } \\ +c \text { los } \\ \beta F\end{array}\right]\right\}$

Condition: Sentence-bounded

The alpha $(\alpha)$ and beta $(\beta)$ conventions in the structural description refer to non-identical or heterorganic consonantal place features. An alternate solution that would not require the alpha and beta conven- 
tions would be to use the Integrity Hypothesis, which avoids splitting geminate clusters. ' This would be extending that hypothes is to include homorganic consonants. We would be considering aspiration as separating consonants in that sense.

By not including voicing in the first consonant member, this same rule can be applied in casual speech also, making it unnecessary to produce a separate casuai speech rule. By not restricting the second consonant member to obstruents, the aspiration occurs before nasals also which would feed a subsequently ordered voiced release rule and result in voiced open transition. The voiced release rule could then be conomically written as:

Voiced Release: $h \rightarrow^{\partial} / C[$ [nasal $]$

Condition: Sentence-bounded

'Michael Kenstowicz and Charles Pyle, "On the Phonological Integrity of Geminate Clusters," in Issues in Phonological Theory: Proceedings of the Urbana Conference on Phonology, eds. Michael J. Kenstowicz and Charles W. Kisseberth (The Hague: Mouton, 1973), pp. 27-43. 


\section{CHAPTER III}

MORPHOPHONEMIC RULES

This chapter describes those rules which are morphologically or morphophonologically conditioned and are applied eariier in derivations than the allophonic processes described in the last chapter. In using the term morphophonemic "rule" we are modifying what Stampe, the originator of the natural phonological model, meant by "rule", as interpreted by Bjarkman. 1 We are in a sense merging Stampe's morphophonemic "processes" and "rules" as opposed to allophonic processes. Morphophonemic rules tend to make more radical substitutions than allophoric processes, and are not effected by casual speech, whereas allophonic processes are, as will be shown in tile casual speech chapter.

\section{Consonant Duplication}

A duplication of a verb stem or suffix-final non-glotial consonant occurs when followed by the completive aspect marker $/-w \dot{q} /$, in which case the $/ \mathrm{w} /$ is deleted in favor of the duplicated consonant. The glottal consonants / $h, ? /$ are not duplicated, and the /W/ of / wi / is retained in these cases. In the case of a verb stem which ends in a non-glottal two consonant cluster, no duplication occurs and the /w/ of / $/ \mathbf{w} /$ is deleted. No other/wi/-initial suffixes occur in $\mathrm{CZ}$,

IPeter C. Bjarkman, "Toward a Proper Canception of Processes in Natural Phonology," to appear in Papers from the Eleventh Regional Meeting, Chicago Linguistic Society (1975). 
however, a /wi/-initial verb stem might be compounded, in which case no consonant deplication occurs, therefore this rule is applicable only to the completive aspect marker $/ w i /$. Note the following data in phonemic form:

Gloss
'sow seeds'
'shave wood'
'guard'
'find'
'erase'
'drown'
'carve'
'nurse'
'be full'
'eat'
'be seen'
'have a cataract'
'die'
'wash'
'put'
'be born'
'bury'
'sharpen'
'come'
'get cloudy'
'bake/burn'
'be lame'
'pulsate'
'hurt'

Incompletive Completive / wi

puppa

he?ppa

kotpa

puppi

pa?tpa

hikpa

ha? kpa

cecpa

cu?cpa

taspa

ki?spa

kehpa

pohpa

ka?hpa

ce?pa

pi?pa

po?pa

kumpa

he?poi

ketti

pa?tti

hikki

ha?kki

cecct

cu?cci

tassi

ki?ssi

kehwi

pohwi

ka?hwi

ce?wa

pi? wi

po?w7

hi?mpa

kummi

minpa

hi? $\mathrm{mm}$ i

?j?npa

minnt

po npa

?i?nni

mi? эpa

pongi

pi?lpa

mi?

toypa

pi?17i

toyyi

\section{In suffixes}

minke?tti
minsukki
minco?cci
minmussi
minha?wiyji

'he came again'

'they came'

'he came first'

'he knew how to come'

'you (pl.) came'

Non-occurrence

Gloss

'go'

'illuminate'

'burn (food)'

'is delicious'
Incompletive

nikspa

ta?kspa

hipspa

hi?pspa
Completive

niksi

ta?ksi

hipsi

hi?psi

From these data two rules can be formulated; one for cuinsonant 
duplication, the other for $/ w /$-deletion:

Consonant Duplication: $w \rightarrow C_{i} / V(?){ }_{[-g l o t} C^{+}{ }_{j}+\dot{+}$

Condition: 1) Completive aspect marker only

2) Word-bounded

/w/ Deletion: $w \rightarrow 0 \quad \underset{[-g \text { lot }]}{\mathrm{C}} \mathrm{C}+\ldots$

Condition: 1) Completive aspect marker only

2) Word-bounded

\section{$\mathrm{lo} /$ becomes $/ \mathrm{w} /$}

A stem-final $/ \mathrm{g} /$ becomes $/ \mathrm{W} /$ preceding a vowel. ${ }^{1}$ This occurs onlu in the cases of the stative morpheme $/-e /$, reciprocal agreement markers /-itah/ and / $-i h /$, and vowel epenthesis. Note the following data:

\begin{tabular}{|c|c|c|c|c|c|}
\hline & 'bathe' & 'burn' & 'clear' & 'fear' & 'sleep' \\
\hline ico & $\begin{array}{l}\text { činpa } \\
\text { cinpj } \\
\text { ciwi } \\
\text { ciwi? }\end{array}$ & 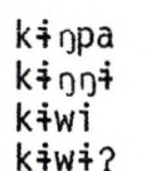 & $\begin{array}{l}\text { sanpa } \\
\text { sanji } \\
\text { sawe } \\
\text { sawi? }\end{array}$ & $\begin{array}{l}\text { hennt } \\
\text { hewe } \\
\text { hewa? }\end{array}$ & $\begin{array}{l}\text { monni } \\
\text { mowe } \\
\text { mowa? }\end{array}$ \\
\hline
\end{tabular}

With reciprocal and other vowel epenthes is forms:

\begin{tabular}{|c|}
\hline $\begin{array}{l}\text { a yconpa } \\
\text { ley a ncowatahp } \\
\text { inpa } \\
\text { ley yakciwihpa } \\
\text { iwi ti?ipa } \\
\text { inpa } \\
\text { lat iwa?am } \\
\text { it npa } \\
\text { lampa niwi }\end{array}$ \\
\hline
\end{tabular}

This is considered to be the simplest synchronically-determined explanation based upon the preponderance of $/ \mathrm{g} /$ over $/ \mathrm{w} /$. Personal conversation with Norman Nordell, another SIL linguist who is doing comparative studies among Zoque and Mixe Tanguages, has caused me to consider an alternate historically-determined rule stating $w \rightarrow 0$ before a consonor pause. This interpretation would consider any surface $/ \mathrm{g} /$ to be an underlying $/ \mathrm{w} /$. A rule of this nature would have to be ordered preceding the consonant duplication and glottal metathesis rules. 
This change does not occur preceding glottal stop-initial morphemes. In the surface structure the glottal stop has metathiesized with the $/ g /$ as a result of the later ordered allophonic glottal metathesis rule:

\begin{tabular}{|c|c|c|c|}
\hline & $\begin{array}{c}\text { 'speak' } \\
\text { (?oton+? }{ }^{2} \text { y) }\end{array}$ & $\begin{array}{c}\text { 'clear' } \\
(\text { saj+?oy) }\end{array}$ & $\begin{array}{c}\text { 'Tean' } \\
\text { (cent? }+ \text { fy) }\end{array}$ \\
\hline Incor & ?oto? nqypa & sa? noypa & ce?ni ypa \\
\hline npletive: & ?oto?niyyi & sa?noyyi & cerpiyyi \\
\hline tative: & ?oto?niyi & sa? noye & ce?niyi \\
\hline nperative: & ?oto? מf? & sa?no? & ce?nit? \\
\hline
\end{tabular}

These facts can be captured in the following morphophonemic rule:

$$
\mathrm{D} \rightarrow \mathrm{W}: \quad \mathrm{D} \rightarrow \mathrm{W} / \mathrm{V}
$$

Condition: Word-bounded

\section{Vowel Epenthesis}

The vowel $/ \dot{q} /$ is epenthesized after a consonant-final verb stem, or non-clitic verb suffix, preceding an optional glottal stop and a word boundary or clitic boundary. The occurrence of the optional glottal stop is in positive singular imperative forms only. The choice between two different boundary markers in the structural description is made necessary by the fact that, though epenthesis occurs without exception before a word boundary in the above environment, it also occurs preceding a small distinctive class of suffixes across whose boundaries all word-bounded rules apply when their conditioning environments are met. Therefore this distinctive class cannot be bounded by word boundaries. They are also unique from regular verb suffixes in that they all, with the exception of one form, /si?/ /si?/ (hortative), can be suffixed to most noun, adjective, and adverb stems as well as verb stems and their suffixes. Regular verb suffixes never have vowel epenthesis occurring preceding them, though they can have it following, 
whereas these special suffixes or clitics always have vowel epenthesis occurring preceding them but never following, i.e., even though most of these clitics are consonant-final, epenthesis never occurs between two adjacent clitics nor after them preceding a word boundary. Thus it can be seen that this class of special suffixes must have a toundary strength situated between morpheme and word boundaries, other than stem boundary, for they are not stems. We will call this a clitic boundary, whose symbol has already been referred to in a previous footnote as $(=)$. As an aid to the reader of the data to follow, where a clitic boundary is pertinent to the epenthesis it will be marked. A space will represent a word boundary. Notice that the epenthetic vowel varies between / $/$ / and /a/ because of vowel harmony which will be described shortly.

\section{Incompletive}

nikspa

kekpa

haypa

?a?mpa

?a?mke?tpa

nikspa

?a?ami minpa

conpa

cikpa

\section{Epenthetic forms}

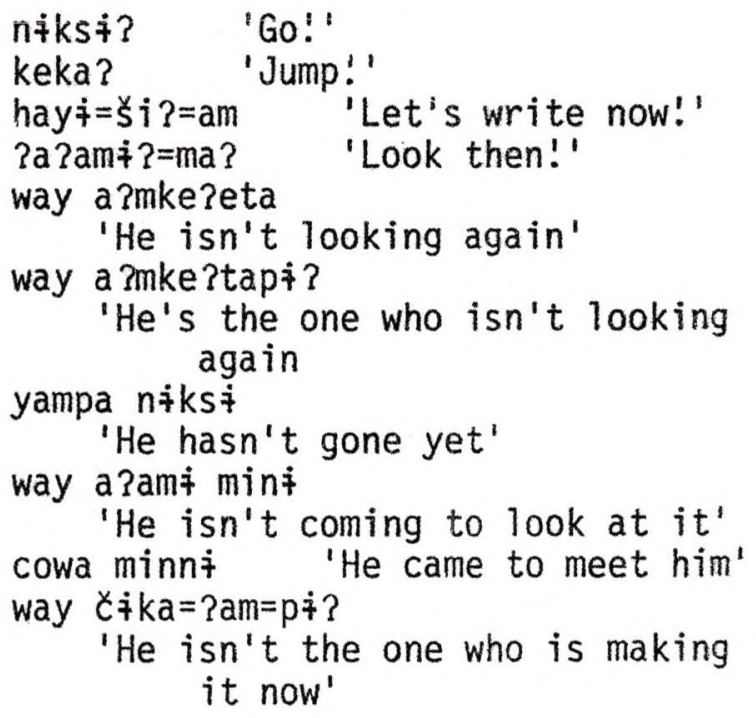


Based on the preceding data, the vowel epenthesis rule can be written as: ${ }^{1}$

Vowel Epenthesis: $\emptyset \rightarrow+/ C(?)=$

Condition: 1) On verb stem and non-clitic verb suffixes only

2) Sentence-bounded

\section{/h/ Deletion}

When a stem ending in $/ ? h /$ precedes a vowel or glottal stopinitial suffix, the $/ \mathrm{h} /$ is deleted, and, in the case of a glottal stop-initial suffix, the resulting glottal stop cluster is reduced to one glottal stop either by the morphophonemic or the allophonic glottal reduction rules. Consider the following data:

\begin{tabular}{|c|c|c|}
\hline Gloss & Incompletive & Imperative \\
\hline $\begin{array}{l}\text { 'die' } \\
\text { 'kill' } \\
\text { 'be killing' } \\
\text { 'take away' } \\
\text { 'bring' }\end{array}$ & $\begin{array}{l}\text { ka?hpa } \\
\text { yakka?hpa } \\
\text { yakka?oypa } \\
\text { niksa?hpa } \\
\text { mina?hpa }\end{array}$ & $\begin{array}{l}\text { ka?a? } \\
\text { yakka?a? } \\
\text { (not used) } \\
\text { niksa?a? } \\
\text { mina?a? }\end{array}$ \\
\hline
\end{tabular}

Other miscellaneous forms using the above stems are:

$\begin{array}{ll}\text { 'death' } & \text { ka?al (ka?h=?aj) } \\ \text { 'he won't die' } & \text { wat ka?a } \\ \text { 'he didn't kill it' } & \text { ha?y yakka?e } \\ \text { 'he came killing' } & \text { yakka?a minni }\end{array}$

${ }^{1}$ An alternative solution to vowel epenthesis is available by considering the vowel to be underlying as in the case of stative /-e/. One difficulty is assignment of a name to an entity that occurs in such divergent forms as imperative, negative imperfect, regative incompletive, and on the main verb of a complex verb phrase. Originally "gerundive" was used as opposed to stative. The difficulty with an underlying vowel solution is that it would be used in the conditioning environment to delete a verb suffix-final /y/ and then itself be deleted to produce the correct output. In the stative case, the underlying vowel did not result in a $/ y /$ deletion. In addition, an underlying vowel solution would fail to call attention to the distinctive class of suffixes which obviously act differently in many areas than regular verb suffixes. 
To avoid possible interpretation of the $/ h /$ as rearticulated [A] before /p/, [ka?hpa] 'he is dying' contrasts with [pa?apa] 'he sifts'.

The resulting $/ \mathrm{h} /$ deletion rule based on these data is as follows: $/ h /$ Deletion: $h \rightarrow \emptyset / ?-\left\{\begin{array}{l}? \\ V\end{array}\right\}$

Condition: Word-bounded

\section{Glottal Reduction}

When two glottal stops are interceded by a clitic boundary, the glottal stop to the left of the clitic boundary is deleted. This rule is important with regard to stress placement where a clitic boundary is involved. This perhaps can best be illustrated by the contrasts in the following derivations:

'it is only high now' 'he is burning' 'only death'

UF:

h-Del:

M.?-Red:

i Umlt.

Pr Str:

Se Str:

IVD:

? Red:

Son Syl:

Surface:

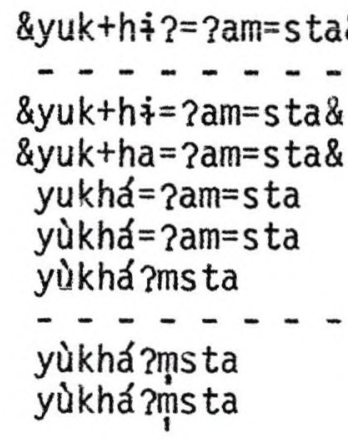

\&yuk $+h ; ?=? a m=s t a \&$

\&yuk $+h \dot{i}=? a m=s t a \&$

\&yuk $+h a=? a m=s t a \&$

yukhá=?am=sta

yùkhá =?am=s ta

yùkhá?msta

yùkhá?msta

yưkhá?mista

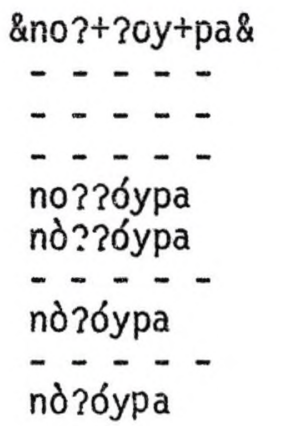

\&ka?h=?a $n=s t a \&$

$\& k a ?=? a n=s t a \&$

$\& k a=? a n=s t a \&$

-....

$k a ́=? a n=s t a$

-.....

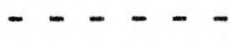

$\cdots$

ká?ànsta

It can be seen in these derivations that if the glottal stop cluster was not reduced in the first and third derivations, it wolild have blocked the placement of primary stress on the first member of a $V_{i} 3 V_{i}$ sequence, which did occur in the second derivation where no clitic boundary occurred.

A morphophonemic glottal reduction rule to express this change can be written:

Gĩottal Reduction: $\quad ?=? \Rightarrow \emptyset=$ ? 
Vowel Harmony

An epenthetic $/ \dot{q} /$ and the $/ \dot{q} /$ of the vowel-initial reciprocal agreement markers/-itah/ and /-ih/ harmonize and become /a/ when the last vowel in the preceding verb stem or suffix is mid $(0, e)$, or when the verb stem ends in $/ \mathrm{a} \mathrm{h} / \mathrm{.}^{1}$ It is interesting that in this last restricted environment the $/ \dot{q} /$ becomes $/ a /$, since in all other $/ a /$-medial verb stems no harmony takes place. The $/ \mathrm{h} /$ deletion rule mentioned previously would be applied later in the derivation to leave the vowel harmony results seen in the following data:

\begin{tabular}{|c|c|c|c|}
\hline Gloss & Incomplet. & Imperative & Neg. Incomplet. \\
\hline 'go' & nikspa & niksi? & wat niksi \\
\hline 'accompany' & niksmotpa & niksmota? & wat niksmota \\
\hline 'kill' & yakka?hpa & yakka?a? & way yakka?a \\
\hline 'take away' & niksa?hpa & niksa?a? & way niksa?a \\
\hline 'pace' & ka?spa & ka?si? & wat ka?si \\
\hline $\begin{array}{l}\text { 'sift' } \\
\text { 'do again' }\end{array}$ & $\begin{array}{l}\text { pa?pa } \\
\text { cikke?tpa }\end{array}$ & $\begin{array}{l}\text { pa?iq? } \\
\text { cikke?ta? }\end{array}$ & $\begin{array}{l}\text { way pa?i } \\
\text { way cikke?ta }\end{array}$ \\
\hline 'wrap' & monpa & mona? & way mona \\
\hline 'peel' & cikpa & ciki? & way čiki \\
\hline 'pul1' & huppa & hupi? & way hupi \\
\hline 'carve' & cecpa & ceca? & way ceca \\
\hline
\end{tabular}

From these data a vowel harmony rule might be written as: Vowe1 Harmony: $i \rightarrow a /\left\{\begin{array}{c}v^{a} h{ }^{c h} \\ {[+ \text { mid }]}\end{array}\right\}+$

\section{Stative Vowel Raising}

Another case of vowel harmony, or what I will call vowel raising also occurs in $\mathrm{CZ}$. The stative/e/ is raised to / $i /$ following a high vowel in the immediately preceding verb stem or suffix. These forms are

${ }^{1}$ The analysis of the reciprocal agreement markers as vowel initial has also been done for Copainala Zoque in William L. Wonderly, "Zoque III: Morphological Classes, Affix List, and Verbs," International Journa? of American Linguistics 17 (July 1951):156. 
found in verbal derived adjectives and negative completive aspect.

Note in the following data that when a non-high vowel occurs preceding the stative, the $/ e /$ is not raised.

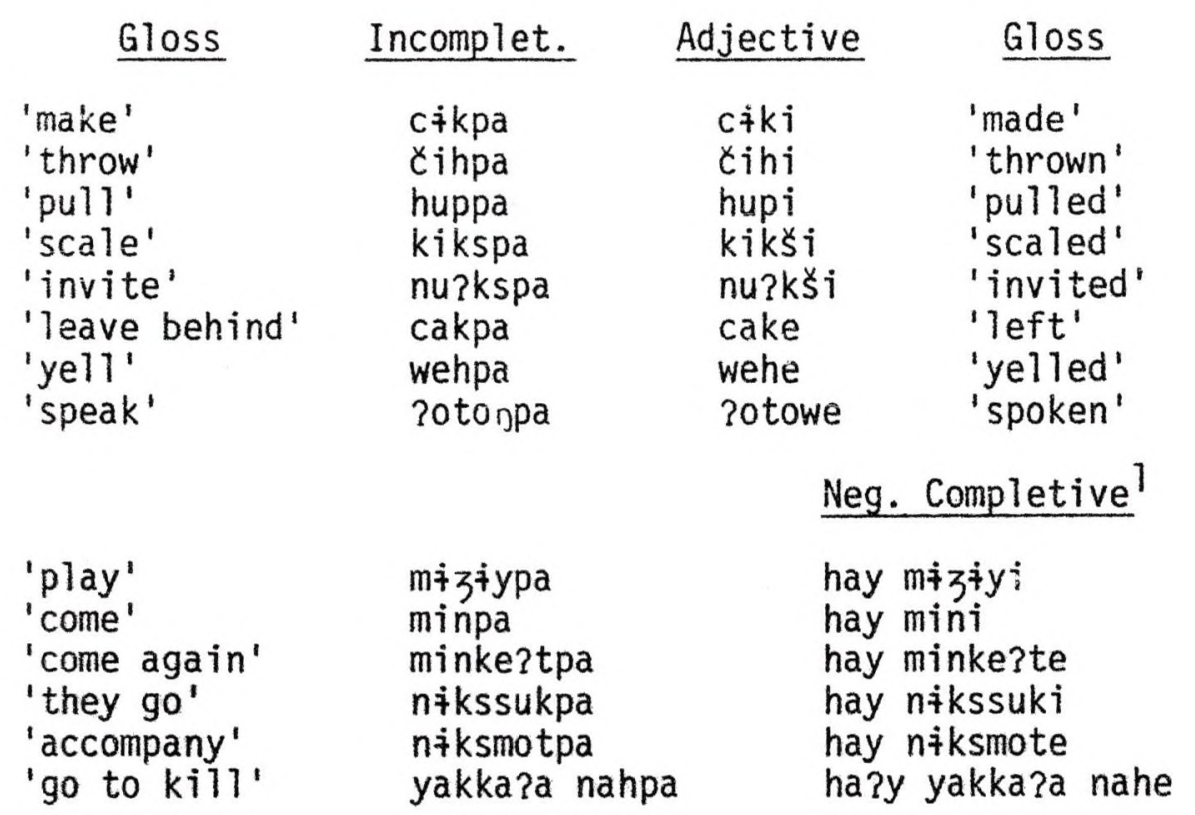

Based on these data, a stative vowel raising rule can be formulated as:

Stative Vowel Raising: e $\rightarrow$ i $/ \underset{[+h i]}{V} \mathrm{C}_{1^{+}}-$

\section{ly/ Deletion}

A verb suffix-final $/ y /$ is deleted before an optional glottal stop and a word or clitic boundary. The optional glottal stop occurs only in the case of positive singular imperative. This $/ y /$ loss bleeds vowel epenthesis and the resulting vowel harmony rule. CZ has six verb suffixes which are/y/-final:/-3iy/(generalizer), /-3oy/ (intransitivizer), /-hay/ (benefactive), /-nay/ (corporeal or aimless),

$1 /$ hay/ is the negative completive marker for third person intransitive, and /ha?y/ is the negative completive marker for third person transitive. 
/-tenay/ (transitive iterative?), and /-ha?wiy/ (second person plural subject). Note the following data:

\begin{tabular}{|c|c|c|}
\hline Gloss & Incomplet. & Imperative \\
\hline $\begin{array}{l}\text { 'play' } \\
\text { 'do for another' } \\
\text { 'stand' }\end{array}$ & $\begin{array}{l}\text { mizłypa } \\
\text { cłkhaypa } \\
\text { mannaypa }\end{array}$ & $\begin{array}{l}\text { mizi? } \\
\text { cikha? } \\
\text { manna? }\end{array}$ \\
\hline & & Neg. Incomplet. \\
\hline $\begin{array}{l}\text { 'drink posol' } \\
\text { 'stare' } \\
\text { 'eat' }\end{array}$ & $\begin{array}{l}\text { ?ugoypa } \\
\text { ?a?mtenaypa } \\
\text { ki?soypa }\end{array}$ & $\begin{array}{l}\text { wat ugo } \\
\text { way a?mtena } \\
\text { wat ki?so }\end{array}$ \\
\hline & & Neg. Imperfect ${ }^{2}$ \\
\hline \multirow[t]{2}{*}{$\begin{array}{l}\text { 'you (pl.) do' } \\
\text { 'throw away' } \\
\text { 'kneel' }\end{array}$} & $\begin{array}{l}\text { cikha?wiypa } \\
\text { ?okpaziypa } \\
\text { kutnaypa }\end{array}$ & $\begin{array}{l}\text { yampay そ̇kha?wi } \\
\text { yampay okpaż } \\
\text { yampa kutna }\end{array}$ \\
\hline & & Hortative \\
\hline \multirow[t]{2}{*}{$\begin{array}{l}\text { 'chat' } \\
\text { 'care for' }\end{array}$} & $\begin{array}{l}\text { camcamnaypa } \\
\text { ?istenaypa }\end{array}$ & $\begin{array}{l}\text { camcamna }=S ̌ i ? \\
\text { ?istena=si? }\end{array}$ \\
\hline & & Desiderative \\
\hline \multirow[t]{2}{*}{ 'you (p1.) go' } & $\begin{array}{l}\text { niksha?wiypa } \\
\text { ('you (p1.) }\end{array}$ & $\begin{array}{l}\text { niksha?wi\#ti?pa } \\
\text { want to go') }\end{array}$ \\
\hline & & Other \\
\hline 'stare' & $\begin{array}{l}\text { Ra?mtenaypa } \\
\text { ('those th }\end{array}$ & $\begin{array}{l}\text { ?a?mtena=sa?an } \\
\text { at stare') }\end{array}$ \\
\hline
\end{tabular}

From these data, the following /y/ deletion rule might be posited:

/y/ Deletion: $y \rightarrow \emptyset /(+?)=$

Conditions: 1) In verbal suffixes only

2) Senter,ce-bounded

$1 /$ wat/ is the negative incompletive marker used with intransitive verbs, whereas the $/ y /$ of /way/ is a pronominal form used with transitive verbs and means 'it'.

$2 /$ yampa/ is a frozen negative imperfect form which is not inflected as a verb form. The additional $/ y /$ is a pronominal form meaning 'it' used with transitive verbs. 
Note in the following derivations the ordering relationships between /y/ deletion and some of the other rules described.

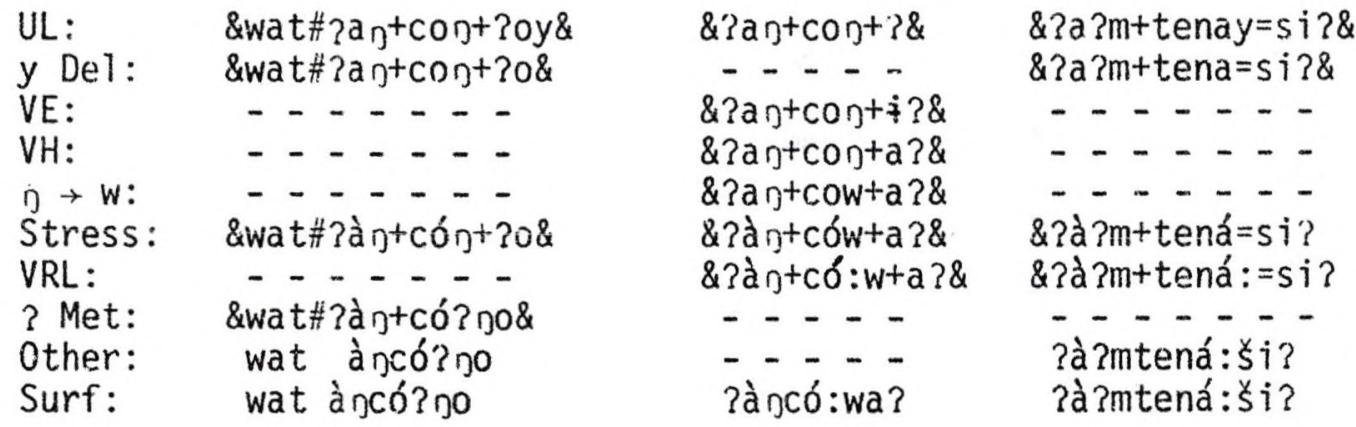

\section{iq/ Umlaut}

A stem or suffix-final $/ \div /$ becomes $/ a /$ preceding the perfective suffix / ?am/ and perceptional suffix/?ag/, excluding monosyllabic stems. 1 The vast majority of these cases involve /?am/ while /?ay/ is more commonly used with numerals or verb stems to form nouns, thereby availing only one known example, since numerals and verb stems are almost all consonant-final.

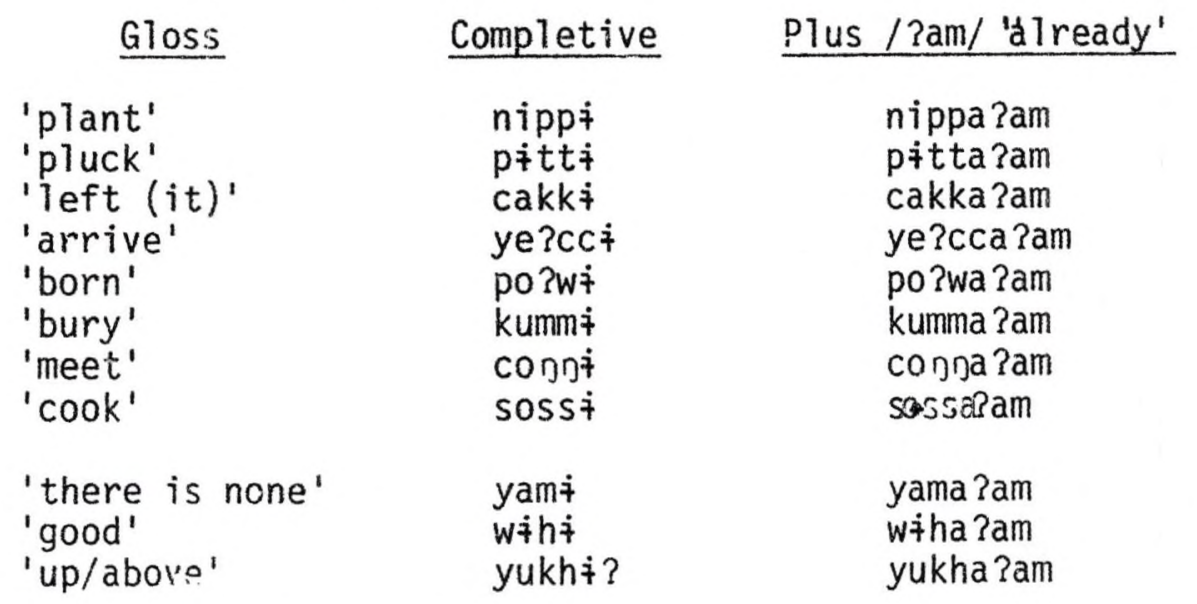

Tone isolated exception is /hi?i/ 'yes'which appears to act as a monosyllabic stem in this situation. 


'one' maktumi $\frac{\text { Plus / Paj/ }}{\text { maktuma?an }}$

But not:

$\begin{array}{lll}\text { 'water' } & \text { niq? } & \text { ní?am } \\ \text { 'this' } & y \dot{q} ? & \text { yं?am }\end{array}$

Other stem-final vowels do not become $/ a /$ in this environment as can be seen below:

Gloss

'big'

'hard'

'awhile ago'

'corn dough'

'inside'

'ahead'

'mud'

'hole'
Plus / ?am/

witi?

paki?

home?

waye

hoho?

winho?

mumu

sutu witi?am

paki?am

home?am

waye?am

hoho?am

winho?am

mumu?am

sutu?am

From these data a rule which we will call / $/$ / umlaut can be written:

/ $/$ Umlaut: $\dot{q} \rightarrow$ a $/\left(C_{1} V\right)_{2}-\left\{\begin{array}{l}\text { ?am } \\ \text { ?an }\end{array}\right\}$

Condition: Word-bounded 


\section{CASUHL SPEECH PKOCESSES}

Casual speech may be defined primarily by an increase in speed of speech flow or relaxed speech serving zase and brevity which results in the effects noted in the processes to be described in this chipter. Casual speech processes form a coexistent or superimposed sy: tell of processes which are ordered miung careful speech allophonic pricesses and are intimately related to them.

\section{CS Glottal Metathesis}

In casual speech a word-initial glottal stop metathesizes with a vord-final sonorant consonant. Specifically, the glottal metathesis rule, which is word-bounded in careful speech, becomes sentenceb. 1 unded in casual speech. When this process occurs, it feeds the $s$ ubsequently ordered sonorant syllabification rule. In the environlient of an unstressed vowel preceding the metathesized glottal stop, a subsequently ordered casial speech glottal deletion rule deletes the metathesized glottal stop and bleeds sonorant syllabification. Thus there may be no apparent evidence of glottal metathesis in some surface forms. A derivation showing this process follows the description of the casual speech obstruent voicing rules. Note the following data shows that the word-initial glottal stop has been deleted by the glottal deletion rule. 


\section{Careful Speech}

te kóm àksímmi te tàm anása ka pán àımáypa ka kán dkhéhpa te kúy o?tcq ył ?n púy úzlkki te doktór òkhéhpa
Gloss

'The post split open'

'The sour orange'

'That man is studying'

'That tiger is resting'

'The tree bent over'

'My thigh is black and blue'
Casual Speech

te kó?m àks ámmł

te tà?mi anása

ka płrñ à omáypa

ka ká? okhéhpa

te kú?y ó?tci

yin pú?y úrkki

te doktó?r dkhéhpa

With Casual Speech Glottal Deletion:

lin áwin écpa

te hálloj ùgóypa

te nakstir in okpazfyyi
'My friend is dancing:

'The boy is drinking posol'

'I thraw away the sling' ?in áwin écpa te hállon ùgóypa

te nàkstir in okpazfyyi

Thus a casual speech glottal metathesis rule based on the above data might appear the same as the careful speech rule except it is sentence-bounded. In relation to order among allophonic processes, this rule would be applied in lieu of the careful speech glottal metathesis rule in fast or unguarded speech.

CS Glottal Metathesis: $\left.\begin{array}{c}C \\ {[+ \text { son] }} \\ 1\end{array}\right] \begin{array}{llllll}C & 3 & & & & \end{array}$

Condition: Sentence-bounded

\section{CS Obstruent Voicing}

Two casual speech obstruent voicing processes occur in $\mathrm{CZ}$. The first process is merely an extension of the careful speech obstruent voicing rule from word-bounded to sentence-bourded. Specifically, a word-final voiceless obstruent becomes voiced preceding a glottal stopinitial word. Here, as in the preceding data, the word-initial glottal stop will not be heard in careful speech due to the glottal deletion rule appitication. 


\section{Careful speech}

te?p a mmaypa

te? apit aksimmi

pa?ak anasa

capac i?ini?

te?y hip ankatti

mok ikspa

pic okho?
Gloss

'he is studying'

'the chayote split'

'sweet orange'

'pink cloud'

'he licked his lips'

'he is shelling corn'

'very low'
Casual speech

te'?b anmaypa

te? apid aksimmi

pa?ag anasa

capaz i?ini?

tey hib ankatt:

mog ikspa

piz okho?

A casual speech obstruent voicing rule based on these data could be written identically to its careful speech counterpart except it unuld be sentence-bounded, and it would be ordered or applied in lieu of the careful spee, h obstruent voicing rule. This parallel between the preceding glottal meiatinesis and this obstruent voicing rule emphasizes the superimposed state of casual speech processes in relation to the careful speech allophonic processes, ready to be applied in Tieu of their careful speech counterparts during fast or unguarded speech, and disregarding the word boundaries which block the reguiar allophonic processes. Here then is the formulated rule:

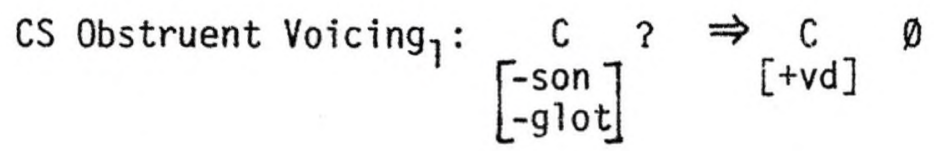

Condition: Sentence-bounded

It can be seen that this rule must be applied before the careful speech glottal deletion rule, otherwise its conditioning environment will be lost. This rule, in fact, bleeds the glottal deletion rule, since the glottal stop is lost in the process of voicing the preceding obstruent.

Voiceless obstruents also become voiced in casual speech when preceding sonorant consonants. Note the following data: 
Careful Speech

yugâp ladu

kepmotti

te? apit widiypa

ha? tmuspa

?ik nikspa

yakmannaypa

cecmuspa

te pac missu?kpa
Gloss

'ulpper side'

'he kicked also'

'the chayote grows'

'he can make twine'

'Who is going?'

'he stands it up'

'he knows how to carve'

'the skunk stinks'
Casual Speech

yugab ladu

kebmotti

te? apid widiypa

he? dmuspa

? g $g^{\text {ə }}$ nikspa

yag gemannaypa

cezmuspa

te paz missu?kpa

A second casual speech obstruent voicing rule might be formulàted as:

CS Obstruent Voicing ${ }_{2}$

$$
\left[\begin{array}{c}
\mathrm{C} \text {-son } \\
\text {-glot }
\end{array}\right] \rightarrow[+v d] /-c c
$$

\section{Condition: Sentence-bounded}

As is the case in careful speech, /s/ is an exception in both of the obstruent voicing rules. The allophonic rule $z \rightarrow s$ can be applied to these rules' outputs to result in the correct surface forms.

It might be argued that, if the glottal deletion rule were applied first, the preceding two casual speech obstruent voicing rules could then be combined by stating a voiceless obstruent becomes voiced preceding a voiced segment, i.e., a vowel or a sonorant consonant. This solution, in spite of its simplicity, has not been chosen for two reasons. First, within no $\mathrm{CZ}$ word does a voiceless obstruent ever become voiced when followed by a vowel or even when it is intervocalic. For example, /kitukpa/ 'he passes' never becomes [*kidukpa*], nor does /pete/ 'swept' ever become [*pede*] in casual speech. Secondly, and most importantly, in careful speech it has been shown that the glottal stop has the effect of moving to the left and voicing a preceding vciceless obstruent, while passing through an already voiced sonorant consonant or metathesizing. The fact that glottal metathesis occurs across word boundaries in casual speech, which was shown previously, 
has caused me to choose the glottal stop as the voicing element, for then bcth the glottal metathesis and obstruent voicing rules in careful speech can be merely expanded from word-bounded to sentencebounded in casual speech, resulting in better symmetry.

Some of the ordering relationships of the three rules described above with other allophonic processes can be seen in the following derivations.

'the sour orange'

UL: $\quad$ \&te?\#tam\#?anasa\&

Stress: \&te?\#tàm\#?anása\&

VRL: \&te?\#tàm\#?aná:sa\&

CS ? Met: \$te?\#tà?m\#aná:sa\&

Son Syl: \$te?\#tà?m\#aná:sa\&

?Del: \$te\#tà?minaná:sa\&

Surface: te tà?mi aná:sa

'the boy drinks posol'

UL: $\quad$ \&te?\#hallon\#?uk+?oy+pa\&

Stress: \&te?\#hál1on\#?uk+?oy+pa\&

VRL: $\quad--\overline{-}-\overline{-}-\overline{-}$

CS ? Met: \&te?\#hállo?n\#ùk+?óy+pa\&

$\mathrm{CS} \mathrm{Ob} \mathrm{Vg}_{1}$ : \&te?\#hállo?\#\#ùgóypa\&

CS Ob Vg $g_{2}: \quad \ldots-\ldots$

IVL:

\& t e?\#hál10?\#ù.góypa\&

CS ? Del: \&te?\#hállon\#ù.góypa\&

? Del: \&te\# hállon\#ù.góypa\&

Surface: te hállon ù.góypa\&

'his tooth is growing'

UL: $\quad$ \&te $?+p+? \dot{q} y \# t+c \# w i t+? \dot{q} y+p a \&$

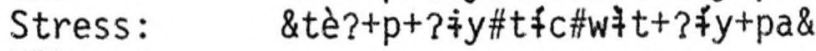

VRL: $\quad-\ldots-\ldots$

CS ? Met: $\quad-\ldots-\ldots-\ldots$

CS $0 \mathrm{~b} \mathrm{Vg}$ : \&tè?biy\#tfc\#widfypa\&

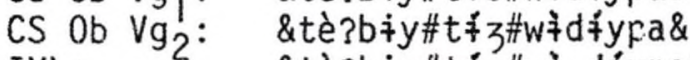

IVL:

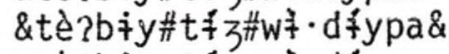

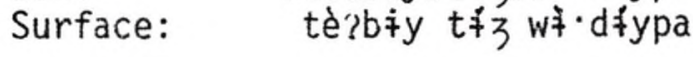




\section{CS / c/ Deletion}

In casual speech, the word-final /c/ of / $\mathrm{q} \mathrm{c} / \mathrm{c}$ 'I', /mic/ 'you', and /pic/ 'very/really' is deleted preceding a consonantal-initial word, excluding glottal stop, and varies between deletion and voicing preceding /w/ or /y/-initial words. Note the following data:

Careful speech Gloss Casual speech

\begin{tabular}{|c|c|c|}
\hline $\begin{array}{l}\text { c pic ni? uki } \\
\text { ti?ipa }\end{array}$ & 'I an & $k \dot{q}$ \\
\hline nikspa?am & I am going now' & ?ł nikspa?am \\
\hline & heavy' & pi hemec \\
\hline withi. & 'It is very pretty' & pi wiht \\
\hline$k \dot{q}$ & 'It is very cute' & pi tukki \\
\hline jiyyi & 'You entered' & mi tigizyyi \\
\hline $\mathrm{t} \mathrm{niksi}$ & 'You aren't going' & mi wad nikst \\
\hline ka?hpa & am hungr & ?ł yukka?hpa \\
\hline
\end{tabular}

When $/ c /$ precedes a glottal stop-initial word, the earlier ordered first casual speech obstruent voicing rule is applied, thus $/ \mathrm{c} /$ becomes $/ 3 /$ and it is not deleted. Since this process bleeds /c/ deletion, no non-glottal stop specification need be included in the rule's structural description. In the careful speech data following, the later ordered glottal deletion rule has been applied, thus the word-initial glottal stop is not pronounced:

\begin{tabular}{|c|c|c|}
\hline Careful speech & Gloss & Casual speech \\
\hline ?+сc anmaypa & 'I am studying' & $2 \ddagger 3$ a nmaypa \\
\hline ?ic okhehpa & 'I am resting' & $2+3$ okhehpa \\
\hline pic etci & 'He really danced' & piz etci \\
\hline pic okho? & 'It is very low' & pis okho? \\
\hline mic ukki & 'You drank' & miz ukki \\
\hline mic otonpa & 'You speak' & mi3 otonpa \\
\hline
\end{tabular}

It can be noted in the preceding data that if the second casual speech obstruent voicing rule were applied before /c/ deletion, /c/ would become voiced before sonorant consonants, rather than being deleted. To arrive at the correct surface form, therefore, /c/ dele- 
tion must be ordered between the two casual speech obstruent voicing rules. Since $/ c /$ is variable before the semivowels $/ y, w /$, it seems feasible to write a separate rule to cover that situation. Two rules, therefore, can be formulated from these data:

$$
\begin{aligned}
& \text { CS/c/ Deletion: } c \rightarrow \emptyset / \#[+ \text { cons }] \\
& \text { Condition: With } / 2 \dot{+c} /, / \mathrm{mic} /, / \text { pic/ only } \\
& \text { CS /c/ Fluctuation: } c \rightarrow \emptyset / \#\left[\begin{array}{l}
\text {-cons } \\
-\mathrm{syl}
\end{array}\right] \\
& \text { Condition: 1) With } / \text { ic/, /mic/,/pic/ only } \\
& \text { 2) Optional }
\end{aligned}
$$

is aking / c/ deletion optional in the second rule, if the rule is not applied the /c/ will then be voiced by the following second casual speech obstruent voicing rule as can be seen in the following derivations:

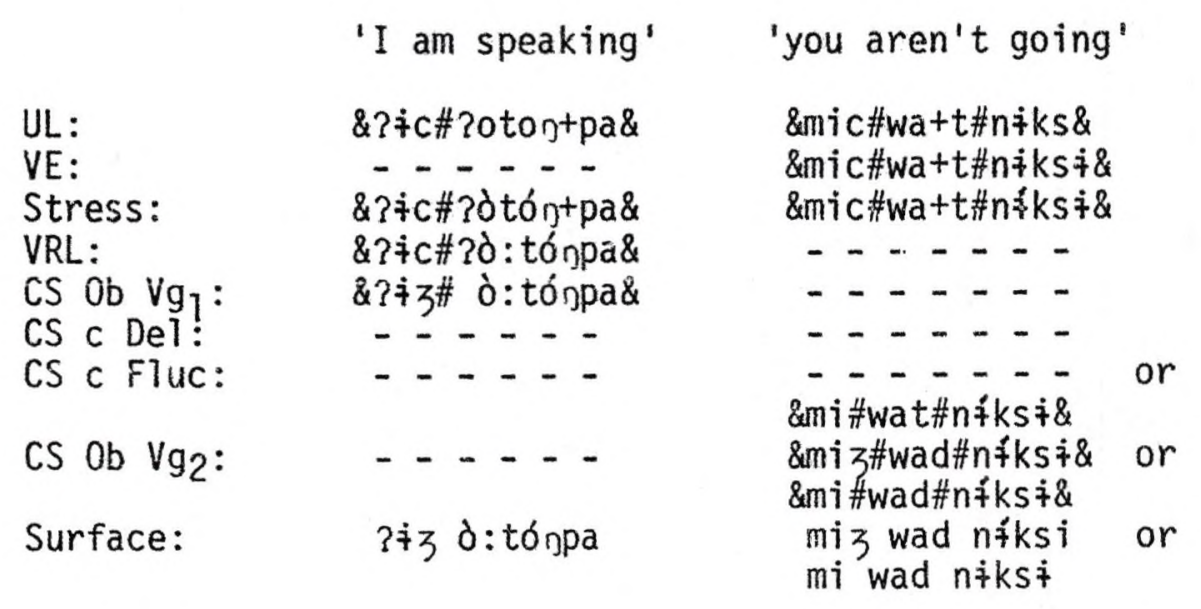

Whether the CS/c/ fluctuation rule is applied or not the resulting surface form will be acceptable.

\section{CS Sibilant Palatalization}

It was stated previously that the sibilants $/ \mathrm{c}, \mathrm{s} /$ became palatalized before / $i /$, and that this allophonic process did not occur across word boundaries. In casual speech $/ J /$ and $/ S /$ can occur before 
$/ y /$ across word boundaries. In the case of $/ 3 / /$, the casual speech obstruent voicing rules apply to $/ \mathrm{c} /$, resuiting in $/ 3 /$ which is then palatalized to $/ \mathrm{J} /$ before $/ \mathrm{y} /$. This process is also applied to Spanish loan words. For example, Spanish siempre [syémpre] 'always' is pronounced as [šyémpre] and juicio [hwísyo] 'just' becomes [ß̈wísyu] in Zoque. Note the Zoque data below:

\section{Careful speech}

3isyonpa

sacyonpa

?ic yek yihi?

te pi?nis yakhenni
Gloss

'he is watching it fall'

'he is wiping it off'

'I am here'

'the man scared him'

\section{Casual speech}

?išyonpa

sałyonpa

?ij yeg yihi?

te pi??nis yakhe on

From these data, a casual speech sibilant palatalization rule might be written:

CS Sibilant Palatalization: [+sib] $\rightarrow[+p a 1] / y$

Condition: Sentence-bounded

\section{CS/ga/ Deletion}

The verb prefixes /yagan-/ (/yak/ (causative) plus /?3g/ (perceptionail)) and / ?ogan-/ (/?ok/'clownward motion' plus/?an/) are reduced to /yan-/ and /30 $-/$ respectively in casual speech:

\section{Careful speech}

yaga jka?mpa

yaga nco ᄁpa

yaga nwakpa

?ogance?giуypa

?oga nme? żypa $\underline{\text { Glos:S }}$

'he is closing it'

'he is setting it on fire'

'he is opening it'

'he is asking'

'he is going around searching'
Casual speech

ya nka?mpa

ya nconpa

ya nwakpa

?once?giypa

?orme?ziуpa

From these data the following casual speech /ga/ deletion rule can be written:

$$
\text { CS/ga/ Deletion: ga } \rightarrow \emptyset /\left\{\begin{array}{l}
\text { ya } \\
? 0-0 \\
0-
\end{array}\right\}
$$

Condition: Word-bounded 
CS Glottal Deletion

In casual speech, a glottal stop is deleted when occurring between an unstressed vowel and a sonorant consonant which is followed by a consonant or word boundary. This rule would be fed by the identical vowel deletion rule and it in turn would bleed sonorant syllabification. Note the following data:

Careful speech

?à?mpa ?ṃné?ete?

yòspa?m 'hóho?

ka kúhủ? isóypa

hòksku?y'ánstion

pòno?np??ista

wàya? isso

colko?yhé?en

kùhu?phé?p̧sta
GToss

'he is looking now also'

'he is already working inside'

'that black bird is alert'

'weeding season'

'only the one that is weak'

'it's a cold place'

'with the heart'

'only with the black bird'
Casual speech

?à?mpamné?ete?

yòspam hóho?

ka kúhun isóypa

hòkskuy ánstion

pononpfi? ista

wàyay isso

cokoyhé?en

kùhughé? psta

From these data, the following casual speech glottal deletion rule can be formulated:

CS Glottal Deletion: $\quad 3 \rightarrow 0 / \underset{[- \text { str }]}{V}-\underset{[+ \text { son }]}{C}\left\{\begin{array}{l}C \\ \#\end{array}\right\}$

\section{CS $/ \mathrm{h} /$ Doubling}

When a stem ending in $/ \mathrm{Vh} /$ precedes a glottal stop-initial suffix, the glottal stop becomes $/ \mathrm{h} /$ in casual speech, resulting in an /hh/ cluster. Con der the following data:

\begin{tabular}{|c|c|c|}
\hline Gloss & Careful speech & Casual speech \\
\hline 'cleared land' & yuh?an & yuhhan \\
\hline ' it abounds' & sth?iypa & sihhiypa \\
\hline 'he is clearing land' & yuh?oypa & yuhhoypa \\
\hline 'it is coming loose' & woh?impa & wohhimpa \\
\hline 'he is throwing' & čih?oypa & tihnoypa \\
\hline 'he is complaining' & ?ih? thpa & ?ilihihpa \\
\hline
\end{tabular}

Across word boundaries the pre-ordered careful speech glottal deletion rule would delete a word-initial glottal stop, thus bleeding 
60

this process and effectively making it word-bounded:

CS $/ \mathrm{h} /$ Doubling: Vh $? \Rightarrow$ Vhh

Condition: Word-bounded 
CHAPTER $V$

LOAN PHONOLOGY

In this chapter we are describing those distinctions or conflicts in the pronunciation of a non-native Zoque loan word in its Zoque context as opposed to its original foreign context. Several points must be considered in such a description. Since for CZ speakers two separate phonemic systems appear to coexist, the likelyhood of fewer completely assimilated forms would be higher, especially when considering newly borrowed words. Describing assimilation processes by means of rules is difficult, since the rules must apply to an uncertain underlying form due to the fact that we do not know how a Zoque speaker hears a foreign word. Sequences of sounds can be misinterpreted, or features of pronunciation can pass unheard, so that the Zoque speaker's assimilation rules may be applied to a sequence considerably different than its original foreign pronunciation. The factor of time must also be considered. Words borrowed at an earlier date are more likely to be completely assimilated. Assimilation rules which were perhaps obiigatory at one point in history appear to be lost, or not applied at all at the present time, perhaps only traceable by those few forms which were fully assimilated, lexicalized, and passed down from a former generation of Zoque speakers to the new as internal to the $C Z$ system. As might be expected, for most loan words there are forms freely varying between those iess and more assimilated to Zoque. The possibility has been alluded to that less assimilated forms provide 
evidence for a specific underlying form, i.e., the sequence of sounds in the foreign word have not been misinterpreted, while the more assimilated forms represent the application of assimilation rules. ' In the description of assimilation processes we will provide evidence of varying forms where they are found to exist.

Loan words spoken by speakers of Zoque are borrowed predominantly from the Spanish language, with the exception of perhaps a few Zapotec words borrowed from the Isthmus Zapotecs who reside nearby, and with whom most contact is made outside the Zoque speaking community.

\section{Internalized Loan Words}

There are several Spanish loan words in common usage among $\mathrm{CZ}$ speakers today which we will classify as internalized loan words, those that have been assimilated, lexicalized, and passed down, and are now considered "truily Zoque." Most of these words have passed through radical assimilation processes which have no current application, and if so, are limited versions of the original processes. Though this paper deals with phonological rules with current application, I believe a description of some of the processes that are traceable through these internalized loan words give clues about the limited versions of those processes which may be applicable today and also give evidence of some of the morpheme structure constraints inherent to Zoque. I will therefore list some of these words and

"Richard Rhodes, "Natural Phonology and MS Conditions," Papers from the Eighth Regional Meeting, Chicago Linguistic Society (Apprit 1972):544-57; and Julie B. Lovins, "Why Loan Phonology is Natura 1 Phonology," Papers from the Parasession on Natural Phonology, Chicago Linguistic Society (Apri1 1974):240-50. 
comment on the probable processes which are evidenced by a c ison with the Spanish pronunciation.

[ki:né:ya]: Spanish guineo [ginéo] 'small banana.' Word-initial obstruent devoicing, $\mathrm{CZ}$ secondary and primary stress with accompanying vowel lengthening, and eperithetic /y/ to separate vowel cluster.

Final /a/ could be misinterpretation of Spanish feminine gender.

[ti:yus]: Spanish dios [dyós] 'God' used in the context of [tì:yuskotó:ya?] 'thank you.' Word-initial obstruent devoicing, Cz primary stress placement and vowel length, epenthetic /y/ to separate vowel cluster, and $/ 0 /$ raising to $/ \mathrm{u} /$.

[wá:kas]: Spanish vaca [báka] 'cow.' Word-initial /w/ possibly a misinterpretation of fricative [b] in context of [la báka] 'the cow', vowel length when stressed, final is/ probably from plural, though this form normally refers to a single cow.

[pà:tá:nus]: Spaanish plátano [plátano] 'banana', used in CZ context as 'Targe cooking banana' as opposed to eating banana given above. Nord-initial consonant cluster reduced to /p!; CZ stress pattern and vowel length, $/ 0 /$ raised to $/ \mathrm{u} /$, and possibly a plural $/ \mathrm{s} /$.

[máyña]: Spanish mañosa/o [mañósa] 'sly.' /y/ epenthesis to conform to $\mathrm{CZ}$ allophonic [n] environment, deletion of /os/ internal segment.

[pá:yu]: Spanish pariuelo [panwélo] 'handkerchief.' Probable /y/ epenthesis preceding $/ \mathrm{K} /$ followed by deletion of complex sequence /riwel/ and final /o/ raising to /u/. Deletion of internal cluster resulted in vowel lengthening.

[?à:kú:sa]: Spanish aguja [?agúha] 'needle.' CZ secondary and primary stress with vowei length, medial /g/ devoiced in a Zoque 
voiceless environment (no glottal stop following), eariy Spanish / $/ 5 /$ (presently $/ \mathrm{h} /$ ) de-palatalized since not preceding $/ \mathrm{i} /$.

[?á:Sıj]: Spanish ajo [?áho] 'garilic.' Long vowel on stress, early Spanish /S/ (h) de-palatalized since not preceding /i/ or following $/ y /, / 0 /$ raised to $/ \mathrm{u} /$, and final plural $/ \mathrm{s} /$.

[ká:pwe]: Spanish café [kafé] 'coftee.' Irregular stress changed to penultimate, /f/ substituted by sequence/pw/ which is the only sequence in which native $[\mathrm{p}]$ occurs, and which closely approximates $/ \mathrm{f} /$. Vowel length proves fact of assimilation and not hearing error, since a consonant cluster would block vowel length in native $\mathrm{CZ}$ words.

The few exampies given above provide evidence of a previous procass that devoiced word-initial viced obstruents, since none occur in that position in native $\mathrm{CZ}$ words. This rule is no longer in effect, trizugh these few internalized forms retain the effects of such a rule. A rule previously existed which raised all occurrences of $/ 0 /$ to $/ u /$. A modicied form of such a rule is currently in effect at the present time, which raises a word-final $/ 0 /$ to $/ u /$. There is a constraint in $\mathrm{CZ}$ against vowel clusters, thus the $/ \mathrm{y} /$ epenthesis process which occurred between two clustered vowels is still in effect. No current rule exists which deletes word-initial or word-medial complex sequences. The substitution of the sequence /pw/ for Spanish /f/ is still a current rule, as will be described.

There exist many shortened forms for Spanish proper names which have become internalized which shed light on the relationship of /1/ and $/ r /$ in CZ. Two other words are also included in the following data: 


\section{Gloss}

'Mary'

'Jerome'

'Norbert'

'Romaldo'

'woodpecker'

' Iame'

\section{Spanish}

maría herónimo norbérto

Pomái do karpintéro

renko

\section{Zoque}

má: 11

hé: 70

nólbe?

lómma?

kaipinté:ru

lénku réjku

These forms show the substitution of $/ 1 /$ for Spanish /r/ wordmedially between non-identical vowels or preceding another consonant. The last $/ r /$ in the word for 'woodpecker' is an exception. Wordinitial $/ \boldsymbol{r} /$ is substituted by a variation between $/ 1 /$ and $/ r /$. These tendencies are also seen in native $C Z$ words. One native $C Z$ word has been found in which $/ 1 /$ and $/ r /$ vary freely word-initially: /1innaypa/ ' rignaypa/ 'he is stretching his neck to look.' With the exception of the above internalized forms, these processes are no longer applied to newly borrowed words.

\section{/o/ Raising}

A word-final /0/, which designates masculine gender in Spanish, is raised to / $/ \mathrm{h}$ by most $C Z$ speakers. This process provides a good example of a variation between a less-assimilated and a more-assimilated form, as is shown below:

\begin{tabular}{lll}
\multicolumn{1}{c}{ Gloss } & Less-assim. & More-assim. \\
\cline { 2 - 3 } & pé:so & pé:su \\
'peso' (money) & pú:ro & pú:ru \\
'horse' & kà:bá:yu? \\
'fierce/bad' & pyé:ro & pyé:ru pyé:ru \\
'Tito' (name) & tí:to & títtu \\
'burro' & bú:ro & bú:ru \\
'just/fair' & pwí:syo & pwí:šyu
\end{tabular}

The fact that there is a variation proves the operation of a changing process. On that basis a loan word rule raising a word-final /o/ to /u/ will be formulated as: 
Loan /o/ Raising: $0 \rightarrow u /$ (?)\#

Condition: Loan words only

\section{/f/ and /hw/ Substitution}

A Spanish /f/ or /hw/ (the latter written ju in Spanish) becomes [pw] preceding any vowel. An /f/ preceding a consonant (including $/ w, y /)$ becomes $[p]$. Mention should be made here that most Zoque contact with the Spanish language is made in the nearby Zapotec area of the Isthmus of Tehuantepec. There is a tendency among those Zapotecs to pronounce Spanish names such as Juan [hwan] 'John' as [fan], thus substituting [f] for Spanish [hw]. This factor may have influenced the $C Z$ substitution for $[\mathrm{hw}]$, although [pw] and [hw] are very close acoustically. / $f /$ is not native to $C Z$, therefore the substitution of [ßW] was apparently made since that sequence was the closest acoustically to $/ \mathrm{f} /$. Since $[\mathrm{\beta}]$ only occurs preceding $/ \mathrm{W} /$ in native $\mathrm{CZ}$, it was substituted as a unit. The labial [W] was lost preceding a consonant, probably for the facility in pronunciation. Taking this a step further a tendency is developing to drop the fricative feature of [ $\beta$ ] before $/ y /$, thus $[p y]$ varies with $[p y]$ for Spanish $[f y]$. Contrary to the last rule, in which there were variant forms, these processes are consistent, in fact, native Zoque speakers who are bilingual in Spanish make these substitutions while speaking Spanish. The data illustrating these processes will therefore be presented by a comparison

between the Spanish pronunciation and the Zoque pronunciation. 


\begin{tabular}{cll} 
Gloss & Spanisn & \multicolumn{1}{c}{ Zoque } \\
'John' & hwán & pwán \\
'just' & hwísyo & pwí:šyu \\
'Fidel' & fidél & pwí:de'? \\
'Ralph' & pafaél & pápwa? \\
'Wilfred' & bilfríto & bilpri? \\
'game' & hwégo & pwé:go \\
'fire' & fwégo & pwé:go \\
'fierce' & fyéro & pyé:ru pyé:ru \\
'holiday' & fyésta & pyésta pyésta
\end{tabular}

The following rules can be written to show these processes:

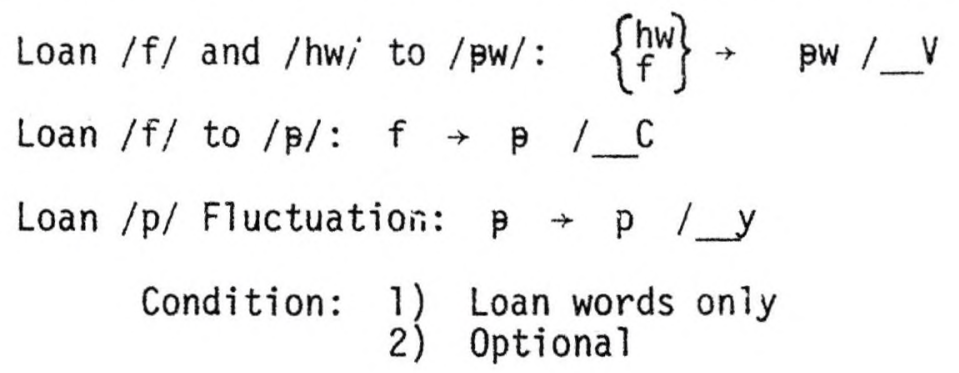

\section{/y/ Epenthesis}

There is a constraint in $\mathrm{CZ}$ against vowel clusters, thus a Spanish loan word which has a vow cluster has an epenthetic /y/ inserted between the vowels. As in the previous rules, there are no less as opposed to more-assimilated forms with regard to $/ y /$ epenthesis.

\begin{tabular}{lll} 
Gloss & Spanish & \multicolumn{1}{c}{ Zoque } \\
'uncle' & tío & tí:yu \\
'banana' & ginéa & kìné:ya \\
'go for walk' & paséa & pà:seyacíkpa
\end{tabular}

A rule to show this epenthesis could be written as:

$/ y /$ Epenthesis,$~ \emptyset \rightarrow y / N$

Condition: Loan words only

A second / $y /$ epenthesis process, which has varying forms, applies in the case of Spanish loan wordr in which / $\tilde{n} /$ occurs. In such a situation $/ y /$ is epenthesized before the $/ \tilde{n} /$. This epenthesis is applied 
primarily by those $C Z$ speakers wr.o still retain the $[\tilde{n}]$ allophone of $\mathrm{h} /$. Note the varying forms below:

\begin{tabular}{|c|c|c|}
\hline Gloss & Less assimil. & More assimil. \\
\hline $\begin{array}{l}\text { 'mountain' } \\
\text { 'sly' }\end{array}$ & mòntă: గa & $\begin{array}{l}\text { mòntáyña } \\
\text { máyña }\end{array}$ \\
\hline 'year' & ?á: గu ?á: గo & ?áynu \\
\hline
\end{tabular}

This second /y/ epenthesis rule could be written as:

/y/ Epenthesis $: \emptyset \rightarrow y / \ldots$

Condition: Loan words only

\section{Other Processes}

The regular Spanish stress pattern is penultimate, thus for the majority of loan words there is no conflict with regard to stress. For those Spanish words which have marked irregular stress, however, that stress is retained in the borrowing. Those loan words which are polysyllabic are assigned a first-syllable secondary stress.

The vowel rearticulation and lengthening rule applies to all loan words in the same manner as native $C Z$ words, as has been illustrateci in all of the preceding examples.

Spanish loan words in which /C/ occurs retain the [C] pronunciation in Zoque, even though it may not occur after $/ y /$ or before $/ i /$. which is its restricted environment in native $C Z$ words. This retention is a good example of the coexistent phonemic distinctions. Note these examples:

\begin{tabular}{|c|c|c|}
\hline Gloss & Spanish & Zoque \\
\hline $\begin{array}{l}\text { 'monkey' } \\
\text { 'job' } \\
\text { 'dog' (pooch) }\end{array}$ & $\begin{array}{l}\text { cángo } \\
\text { cámba } \\
\text { cuco }\end{array}$ & $\begin{array}{l}\text { cángu } \\
\text { cámba } \\
\text { cúčcu }\end{array}$ \\
\hline
\end{tabular}


In the same manner [ร̌], which occurs in one borrowed Isthmus Zapotec word [Šnku?] 'last/dear one' retains [Š] even though it does not occur after $/ y /$ or before $/ i /$.

The above loan word rules would be applied to any foreign word and presumingly would be assigned to a separate phonological component whose output would then pass through the regular CZ morphophonemic and allophonic process applications. 


\section{CHAPTER VI}

\section{RULE ORDERING}

The pertinent interrelationships among the preceding rules have been discussed throughout this paper. The overall orter of application, however, has not been described. This chapter, therefore, provides an index of all the morphophonemic rules and careful and casual speech allophonic processes in the order of their application to underlying forms.

\section{Morphophonemic Rules}

(1) Corsonant Duplication: $w+C_{i} / V(?) \underset{[-g l o t]}{C_{j}}+{ }^{+}$

Conditions: 1) Completive aspect marker only

2) Word-bounded

(2) /W/ Deletion: $w \rightarrow \emptyset / \underset{[- \text { glot }]}{\mathrm{C}} \mathrm{C}+$

Conditions: 1) Completive aspect marker only

2) Word-bounded

(3) /y/ Deletion: $y \rightarrow \emptyset / \ldots(+?)=$

Conditions: 1) In verbal suffixes only

2) Sentence-bounded

(4) Vowel Epenthesis: $\emptyset \rightarrow+/ C \_(?)=$

Conditions: 1) on verb stem and non-clitic verb suffixes onty

2) Sentence-bounded

(5) Vowel Harmony: $\dot{q} \rightarrow a /\left\{\begin{array}{c}v^{a ? h} \\ {[+ \text { mid }]}\end{array} C_{7}\right\}+$ 
(6) Stative Vowel Raising: e $\rightarrow$ i $/ \underset{[+h i]}{\mathrm{V}} \mathrm{C}_{1}^{+}-$

(7) $0 \rightarrow W: \quad 0 \rightarrow W / L$

Condition: Word-bounded

(8) /h/ Deletion: $h \rightarrow \emptyset / ?-\left\{\begin{array}{l}? \\ V\end{array}\right\}$

Condition: Word-bounded

(9) Glottal Reduction: $?=? \Rightarrow \emptyset=$ ?

(10) / $/$ / Umlaut: $\dot{q} \rightarrow \mathrm{a} /\left(C_{7} V\right)_{2}=\left\{\begin{array}{l}\text { am } \\ ? \mathrm{a}_{0}\end{array}\right\}$

Condition: Word-bounded

\section{Allophonic Processes}

(11) Primary Stress $7: V \rightarrow\left[+\right.$ stress 1] $/ \# C_{0}-C_{0} \$$

(12) Primary Stress $2: v_{i} \rightarrow[$ tstress 1$] / \ldots\left(2 v_{i}\right) C_{7}: C_{0} \$$

(13) Secondary Stress: $V \rightarrow[+$ stress 2$] / \$ C_{0} \quad\left(C_{7} V\right)_{2}$

Condition: Excluding monosyllabic pronominal or pre-verbal stems

(14) Vowel Rearticulation and Lengthening:

$$
\emptyset \rightarrow v_{i} / \begin{gathered}
v_{i} \\
{[+s t r]}
\end{gathered} \quad \text { (3) }-\left\{\begin{array}{c}
c \\
{[-g / 0 t]} \\
h
\end{array}\right\} v
$$

Condition: Word-bounded

(15) Identical Vowel Deletion: $V_{i} \rightarrow \emptyset / C_{1} V C_{1} V_{i} ? \underset{[+ \text { nas }]}{C}=C$

Condition: Sentence-bounded

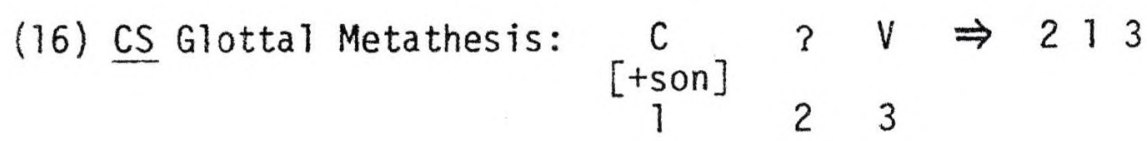

Condition: Sentence-bounded

(17) Glottal Metathesis: $C$ ? $V \Rightarrow 213$

[tson
1 2

Condition: Word-bounded 
72

(18) CS Obstruent Voicing

$$
\underset{\left[\begin{array}{l}
\text {-son } \\
\text {-glob }
\end{array}\right]}{C} \Rightarrow \underset{[+v d]}{C} l
$$

Condition: Sentence-bounded

(19) Obstruent Voicing:

$$
\left[\begin{array}{c}
c \\
\text {-son } \\
\text { slot }
\end{array}\right] \stackrel{C}{C} \emptyset
$$

Condition: Word-bounded

(20) CS /c/ Deletion: $c \rightarrow 0 / \ldots$ [+cons $]$

Condition: With / $\mathrm{iqc} /, / \mathrm{mic} /, / \mathrm{pic} /$, only

(21) $\mathrm{CS} / \mathrm{c} /$ Fluctuation: $c \rightarrow \emptyset / \ldots\left[\begin{array}{l}- \text { cons } \\ - \text { sol }\end{array}\right]$

Conditions: 1) With $/ 3 \dot{i c} /, / \mathrm{mic} /, / \mathrm{pic} /$ only

2) Optional application

(22) CS Obstruent Voicing 2:

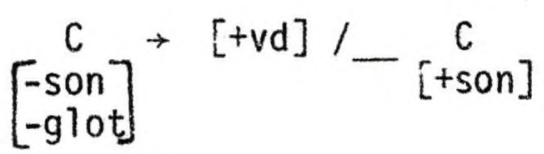

Condition: Sentence-bounded

(23) Intermediate Vowel Lengthening:

$$
\underset{[+s t r]}{V} \rightarrow v \cdot /\left[\begin{array}{c}
c \\
{\left[\begin{array}{l}
-s o n \\
+v d
\end{array}\right]}
\end{array}\right.
$$

Condition: Word-bounded

(24) $z \rightarrow s: z \rightarrow s$

(25) Glottal Reduction: ? ? $\Rightarrow$ ?

(26) CS Glottal Deletion: $\quad \rightarrow \rightarrow / \underset{[-s t r]}{V} \underset{[+ \text { son }]}{C}\left\{\begin{array}{l}C \\ \#\end{array}\right\}$

(27) Sonorant Syllabification: $\underset{[+ \text { son }]}{C} \rightarrow[+$ sal]? $/-\{\emptyset\}$

Condition: Sentence-bounded

(28) CS /ga/ Deletion: ga $\rightarrow \emptyset /\left\{\begin{array}{l}\text { ya } \\ ? 0 \\ 0\end{array}\right\}$

Condition: Word-bounded

(29) /i/ Deletion: $i \rightarrow \emptyset / \mathrm{V}_{[-\mathrm{str}]}{ }^{?} \mathrm{~s}^{\mathrm{s}}$

Condition: Word-bounded 
(30) / + / Deletion: $\underset{[- \text { str }]}{\dot{q}} \rightarrow \emptyset / V+? \_y$

Conditions: 1) Word-bounded

2) Possessive marker only

(31) Glottal Deletion: $? \rightarrow \emptyset /\left\{\begin{array}{l}V \quad \# C \\ C \# \text { \# } \quad V\end{array}\right\}$

(32) Sonorant Devoicing: $\underset{[+ \text { son }]}{\mathrm{C}} \rightarrow[-\mathrm{-vd}] / ?$

(33) Sibilant Palatalization $1:[+$ sib $] \rightarrow[+p a l] / y$

Condition: Sentence-bounded

(34) Sibilant Palatalization $2:[+$ sib] $\rightarrow[+p a l] /$ (C)i

Condition: Word-bounded

(35) CS Sibilant Palatalization: [+sib] $\rightarrow[+p a 1] / y$

Condition: Sentence-bounded

(36) /n/ Palatalization: $\left[\begin{array}{l}\text { tnas } \\ \text { tapic }\end{array}\right] \rightarrow[+$ pal $] / y$

Conditions: 1) Sentence-bounded

2) Optional application

(37) $/ p /$ Lenition: $p \rightarrow p /{ }^{w} \underset{[-s t r]}{V}$

Condition: Word-bounded

(38) CS/h/ Doubling: Vh ? $\Rightarrow$ Vhh

Condition: k'ord-bounded

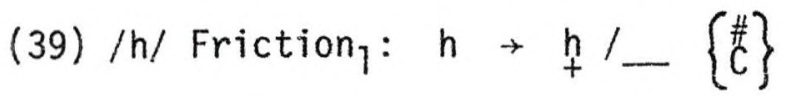

(40) $/ h /$ Friction $_{2}: h \rightarrow h / / V$

$\left[\begin{array}{c}\text { thi } \\ + \text { mid } \\ -b k\end{array}\right]$

C ndition: Optional application

(41) Voiceless Release: $\emptyset \rightarrow h /\left[\begin{array}{l}- \text { son } \\ -g 10 t \\ -s i b \\ \alpha F\end{array}\right]-\left\{\left[\begin{array}{c}\text { \& } \\ +c \text { cons } \\ +c F \\ B F\end{array}\right]\right\}$

Condition: Sentence-bounded 
(42) Voiced Release: $h \rightarrow \partial / C[$ [ ras $]$

Condition: Sentence-bounded 
CHAPTER VII

MORPHEME STRUCTURE

In this chapter we will describe axiomatically those constraints thit exist in the structure of native $\mathrm{CZ}$ morphemes, excluding loan wor ds.

Axiom 1. Nc vowel clusters occur.

When two or more vowels occur in a morpheme or across morpheme bour jaries they are always separated by one or more consonants. This cons traint was made manifest by the $/ y /$ epenthesis to separ. ": vowel clus :ers in loan words.

Axiom 2. A?! fren morphemes are consonant-initial.

The limitation to free morphemes is necessary because of the occu' rence of three bound morphemes which are vowel-initia': stative /-e/ and the reciprocal agreement narkers /-itah/ and /-ih/. 0ther than these morphemes, all morphemes are consonant-initial.

Axiom 3. Any non-syllabic segment except a back nasal / gil may initiate a morphome.

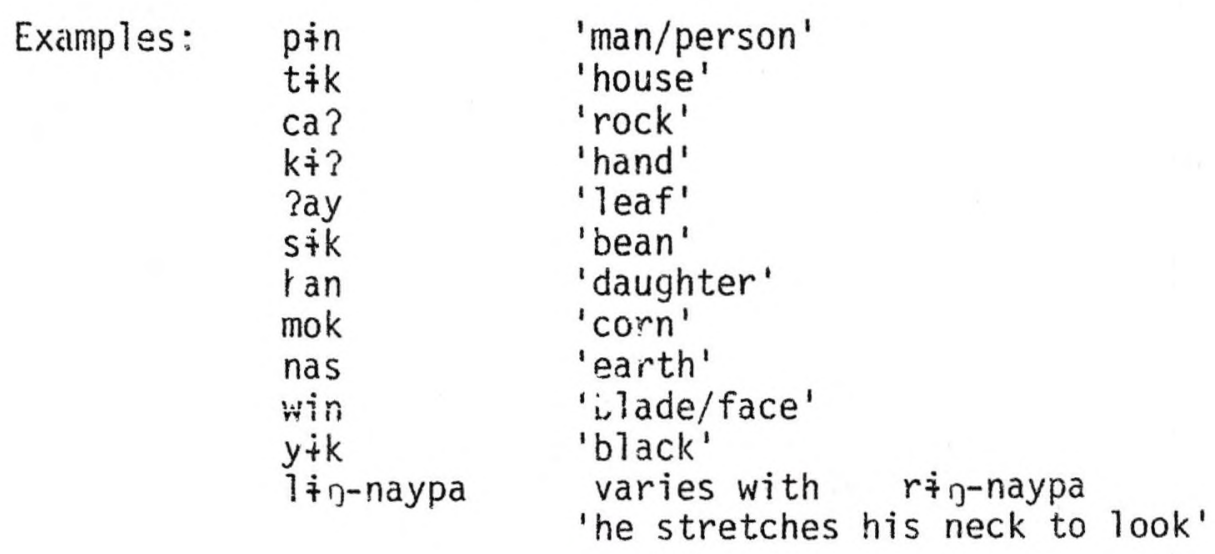


Axiom 4. No consonant clusters except/st/ in /-sta/ 'only' can initiate a morpheme.

The bound form /-sta/ given in the axiom is the only occurrence in $\mathrm{CZ}$ of a consonant cluster-initial morpheme.

Axiom 5. A free morpheme may end in any of the six CZ vowels, a single consonant, or a cluster of two consonants.

\begin{tabular}{|c|c|c|}
\hline \multirow[t]{3}{*}{ amples: } & $\begin{array}{l}\text { ?aka } \\
\text { kini } \\
\text { kape } \\
\text { hohi } \\
\text { hoho } \\
\text { ciku }\end{array}$ & $\begin{array}{l}\text { 'edge' } \\
\text { 'nose' } \\
\text { 'reed' } \\
\text { 'tomorrow' } \\
\text { 'palm tree' } \\
\text { 'badger' }\end{array}$ \\
\hline & $\begin{array}{l}\text { cuk } \\
\text { sah } \\
\text { hip } \\
\text { pin } \\
\text { kuy }\end{array}$ & $\begin{array}{l}\text { 'mouse' } \\
\text { 'wing' } \\
\text { 'mouth' } \\
\text { 'person' } \\
\text { 'tree' }\end{array}$ \\
\hline & $\begin{array}{l}\text { naps } \\
\text { ciks } \\
\text { mu?k }\end{array}$ & $\begin{array}{l}\text { 'purely/really' } \\
\text { 'little' } \\
\text { 'straw' }\end{array}$ \\
\hline
\end{tabular}

Axiom 6. A maximum of three consonants can occur finally in a bound morpheme. The first member of a three consonant cluster must be /?/ and the last member must be /s/. The middle member can be $/ p /$ or $/ k /$.

Examples:

$$
\begin{array}{ll}
\text { hi'iks- } & \text { 'hurry' } \\
\text { me?ks- } & \text { 'carry on hip' } \\
\text { nu?ks- } & \text { 'invite' } \\
\text { ko?ps- } & \text { 'catch' } \\
\text { ki?ps- } & \text { 'to divine' }
\end{array}
$$

Axiom 7. If a morpheme ends in a two consonant cluster, the first member of the cluster must be $/ 3 /, / \mathrm{k} /$, or $/ \mathrm{p} /$. If the cluster is $/ \mathrm{k} /$ or $/ \mathrm{p} /$-initial, the second consonant member is $/ \mathrm{s} /$. If the cluster is glottal stopinitial the last consonant member may be any phoneme except $/ \mathrm{r} /, / \mathrm{w} /$, or $/ \mathrm{l} /$.

$\begin{array}{lll}\text { Examples: } & \text { ciks } & \text { 'Tittle' } \\ \text { niks- } & \text { 'go' } \\ & \text { keks- } & \text { 'snap branches' } \\ \text { napss } & \text { 'purely/really' } \\ \text { sups- } & \text { 'poke with stick' } \\ \text { he p- } & \text { 'grind coarsely' } \\ \text { pa?t- } & \text { 'find' } \\ \text { ha?k- } & \text { 'drown' } \\ \text { wa?c } & \text { 'root' }\end{array}$




$\begin{array}{ll}\text { po?s } & \text { 'guava' } \\ \text { ka?h- } & \text { 'die' } \\ \text { ki?m- } & \text { 'climb' } \\ \text { pi?n- } & \text { 'touch' } \\ \text { hi?n } & \text { 'a plain' } \\ \text { pi?l- } & \text { 'pulsate' } \\ \text { wa?y } & \text { 'hair' }\end{array}$

Axiom 8. If a morpheme ends in a single consonant, / $/$ / and / / / do not occur in that position.

\begin{tabular}{|c|c|c|}
\hline Examples: & $\begin{array}{l}\text { hip } \\
\text { sit } \\
\text { tik } \\
\text { tic } \\
\text { ni? } \\
\text { nas } \\
\text { sah } \\
\text { kom } \\
\text { pin } \\
\text { kan } \\
\text { naks-tir } \\
\text { kuy }\end{array}$ & $\begin{array}{l}\text { 'mouth' } \\
\text { 'mucus' } \\
\text { 'house' } \\
\text { 'tooth' } \\
\text { 'water' } \\
\text { 'earth' } \\
\text { 'wing' } \\
\text { 'post' } \\
\text { 'person' } \\
\text { 'tiger' } \\
\text { 'sling' } \\
\text { 'tree' }\end{array}$ \\
\hline
\end{tabular}

Axiom 9. The following consonant-vowel distribution can occur in a single morpheme: C,CV, CVC, CVCC, CVCCC, V,VC, and VCVC.

\begin{tabular}{|c|c|c|c|}
\hline \multirow{2}{*}{\multicolumn{2}{|c|}{ Examples: }} & $-?$ & (imperative) only occurrence \\
\hline & & $\begin{array}{l}-p a \\
-w q\end{array}$ & $\begin{array}{l}\text { (incompletive) } \\
\text { (completive) }\end{array}$ \\
\hline & CVC: & $\begin{array}{l}t i k \\
\text { pin } \\
\text { (see ot } \\
\text { (mos: } 0\end{array}$ & $\begin{array}{l}\text { 'house' } \\
\text { 'person' } \\
\text { (s above) } \\
\text { non pattern) }\end{array}$ \\
\hline & CVCC: & $\begin{array}{l}\text { ciks } \\
\text { naps } \\
\text { mu?k }\end{array}$ & $\begin{array}{l}\text { 'little' } \\
\text { 'purely/really' } \\
\text { 'straw' }\end{array}$ \\
\hline & CVCCC: & $\begin{array}{l}\text { hi?ps- } \\
\text { nu?ks- } \\
\text { ko?ps- }\end{array}$ & $\begin{array}{l}\text { 'be delicious' } \\
\text { 'invite' } \\
\text { 'catch' }\end{array}$ \\
\hline & V: & $-e$ & (stative) only occurrence \\
\hline & VC: & $-i h$ & (reciprocal agreement marker) \\
\hline & VCVC: & $-i \tan$ & (reciprocal agreement marker) \\
\hline
\end{tabular}


APPENDIX

\section{LIST OF SYMBOLS}

$c=$ Any consonant, including glides $/ w, y, h, ? /$.

$C_{0}=$ Occurrence of zero or more consonants.

$c_{1}=0$ cccurrence of one or more consonants.

$c_{i}=$ Occurrence of identical consonant.

$\mathrm{V}=$ Any vowel.

$v_{i}=$ Occurrence of identical vowel.

$V: \quad=$ Long vowel.

v. $\quad=$ Vowel with intermediate length.

$\breve{V} \quad=$ Unstressed vowel.

$V=$ Vowel with primary stress.

$\dot{V}=$ Vowel with secondary stress.

$\emptyset=$ Null segment; infers deletion of a segment.

$\rightarrow \quad=\quad$ "Becomes" (when one segment is replaced by another)

$\Rightarrow \quad=$ "Becomes" (when several segments are replaced by several others, or change positionally in relation to one another).

$+\quad=$ Morpheme or formative boundary.

$=\quad$ Clitic boundary.

$\# \quad=$ Word boundary.

$\$=$ Stress group or phonological word boundary.

$\& \quad=$ Sentence boundary.

$/ \ldots=$ "In the environment of"

\{\}$=$ Choice of two or more environments within the braces. 
()$=$ When there is no subscript outside the parentheses means the optional occurrence of a segment within. When a subscript number is outside the parentheses, it refers to the minimal number of occurrences of the combined segments within, e.g., $\left(C_{1} V\right)_{2}$ means at least two syllables, each initiated by one or more consonants.

$/ /$ = refers to a particular phoneme or phonemic transcription of a word.

[ ] = refers to a particular phone or phonetic transcripion of a word. When have + or - within, refer to the positive or negative feature noted concerning a segment. 
BIBLIOGRAPHY 


\section{BIBLIOGRAPHY}

Bach, E. and Harms, R. T., eds. Universals in Linguistic Theory. New York: Holt, Rinehart \& Winston, 1968.

Bjarkman, Peter C. "Toward a Proper Conception of Process in Natural Phonology." To appear in Papers from the Eleventh Regional Meeting, Chicago Linguistic Society (1975).

Bolinger, Dwight. "Accent Is Predictable (If You're a Mind-Reader)." Language 48 (1972):633-44.

Chomsky, Noam and Halle, Morris. The Sound Pattern of English. New York: Harper \& Row, 1968.

Crawford, John C. Totontepec Mixe Phonotagmemics. Norman, Okla.: Summer Institute of Linguistics, 1963.

Fries, Charles C., and Pike, Kenneth L. "Coexistent Phonemic Systems." Language 25 (1949):29-50.

Halle, Morris. "Phonology in Generative Grammar." Word 18 (1962):54-72.

Harms, Onhert $T$. Introduction to Phonological Theory. Englewood Cliffs, N. J.: Prentice-Ha]T, 1968.

Kenstowicz, Michael, and Pyle, Charles. "On the Phonological Integrity of Geminate Clusters." In Issues in Phonological Theory: Proceedings of the Urbana Conference on Phonology, pp. 27-43. Edited by Michael J. Kenstowicz and Charles W. Kisseberth. The Hague: Mouton, 1973.

Lovins, Julie B. "Why Loan Phonology is Natural Phonology." Papers from the Parasession on Natural Phonology, Chicago Linguistic Society (April 1974):240-50.

Neeld, Ronald L. "Remarks on Palatalization." In Studies in Phonology and Methodology, pp. 37-49. Working Papers in linguistics, no. 14. Columbus, 0.: Department of Linguistics, Ohio State University, April 1972.

Rhodes, Richard A. "Natural Phonology and MS Conditions." Papers from the Eighth Regional Meeting, Chicago Linguistic Society (April 1972):544-57.

"Some Implications of Natural Phonology." Papers from the Ninth Regional Meeting, Chicago Linguistic Society (Apri1 1973): 530-41. 
. "Non-phonetic Environments in Natural Phonology." Papers from the Parasession on Natural Phonology, Chicago Linguistic Society (April 1974):285-96.

Schane, Sanford A. Generative Phonology. Englewood Cliffs, N. J.: Prentice-Hal1, 1973.

Stampe, David L. "The Acquisition of Phonetic Representation." Papers from the Fifth Regional Meeting, Chicago Linguistic Society $(1969): 443-54$.

"How I Spent My Summer Vacation." Ph.D, dissertation, University of Chicago, 1972, under the title "A Dissertation on Natural Phonology."

Stanley, Richard. "Boundaries in Phonology." In A Festschrift for Morris Halle, pp. 185-206. Edited by Stephen R. Anderson and Paul Kiparsky. New York: Holt, Rinehart \& Winston, 1973.

Wilbur, Ronnie Bring. "When Is a Phonological Rule Not a Phonological Rule? The Morphology of Sierra Miwok." Papers from the Parasession on Natural Phonology, Chicago Linguistic Society (ApriT 1974): 385-95.

Wonderly, William L. "Phonemic Acculturation in Zoüue." International Journal of American Linguistics 12 (1946):9:2-5.

" "Zoque II: Phonemes and Morphophonemes." International Journal of American Linguistics 17 (1951):105-23.

. "Zoque III: Morphological Classes, Affix List, and Verbs." International Journal of American Linguistics 17 (1951):137-62.

Zwicky, Arnold M. "On Casual Speech." Papers from the Eighth Pagional Meeting, Chicago Linguistic Society (Apri1 197):607-is. 